\title{
Seasonal evolution of hydrographic properties in the Antarctic circumpolar current at $170^{\circ} \mathrm{W}$ during $1997-1998$
}

\author{
J.M. Morrison ${ }^{\mathrm{a}, *}$, S. Gaurin ${ }^{\mathrm{b}}$, L.A. Codispoti ${ }^{\mathrm{b}}$, T. Takahashi ${ }^{\mathrm{c}}$, F.J. Millero ${ }^{\mathrm{d}}$, \\ W.D. Gardner ${ }^{\mathrm{e}}$, M.J. Richardson ${ }^{\mathrm{e}}$ \\ ${ }^{a}$ Department of Marine, Earth and Atmospheric Science, North Carolina State University, Raleigh, NC 27695-8208, USA \\ ${ }^{\mathrm{b}}$ University of Maryland Center for Environmental Studies, Horn Point Lab., P.O. Box 775, Cambridge, \\ MD 21613, USA \\ ${ }^{\mathrm{c}}$ Lamont-Doherty Earth Observatory, Columbia University, Palisades, NY 10964, USA \\ ${ }^{\mathrm{d}}$ Rosentiel School of Marine and Atmospheric Science, University of Miami, Miami, FL 33149, USA \\ ${ }^{\mathrm{e}}$ Department of Oceanography, Texas A\&M University, College Station, TX 77843-3146, USA
}

Received 26 July 2000; received in revised form 31 March 2001; accepted 1 April 2001

\begin{abstract}
This paper discusses the seasonal evolution of the hydrographic and biogeochemical properties in the Antarctic Circumpolar Current (ACC) during the US Joint Global Ocean Flux (JGOFS) Antarctic Environment and Southern Ocean Process Study (AESOPS) in 1997-1998. The location of the study region south of New Zealand along $\sim 170^{\circ} \mathrm{W}$ was selected based on the zonal orientation and meridional separation of the physical and chemical fronts found in that region. Here we endeavor to describe the seasonal changes of the macronutrients, fluorescence chlorophyll particulate organic carbon (POC), and carbon dioxide $\left(\mathrm{CO}_{2}\right)$ in the upper $400 \mathrm{~m}$ of the ACC during the evolution of the seasonal phytoplankton bloom found in this area. While the ACC has extreme variability in the meridional sense (due to fronts, etc.), it appears to be actually quite uniform in the zonal sense. This is reflected by the fact that a good deal of the seasonal zonal changes in nutrients distributions at $170^{\circ} \mathrm{W}$ follow a pattern that reflects what would be expected if the changes are associated with seasonal biological productivity. Also at $170^{\circ} \mathrm{W}$, the productivity of the upper waters does not appear to be limited by availability of phosphate or nitrate. While there is a significant decrease (or uptake) of inorganic nitrogen, phosphate and silicate associated with the seasonal phytoplankton bloom, none of the nutrients, except perhaps silicate (north of the silicate front) are actually depleted within the euphotic zone. At the end of the growing season, nutrient concentrations rapidly approached their pre-bloom levels. Inspection of the ratios of apparent nutrient drawdown near $64^{\circ} \mathrm{S}$ suggests $\mathrm{N} / \mathrm{P}$ apparent drawdowns to have a ratio of $\sim 10$ and $\mathrm{N} / \mathrm{Si}$ apparent drawdowns to have a ratio of $>4$. These ratios suggest a bloom that was dominated by Fe limited diatoms. In addition, the surface water in the Polar Front (PF) and the Antarctic Zone (AZ)
\end{abstract}

\footnotetext{
*Corresponding author. Fax: + 1-919-515-7802.

E-mail address: john_morrison@ncsu.edu (J.M. Morrison).
} 
just to the south of the PF take up atmospheric $\mathrm{CO}_{2}$ at a rate 2-3 times as fast as the mean global ocean rate during the summer season but nearly zero during the rest of year. This represents an important process for the transport of atmospheric $\mathrm{CO}_{2}$ into the deep ocean interior. Finally, the net $\mathrm{CO}_{2}$ utilization or the net community production during the 2.5 growing months between the initiation of phytoplankton blooms and mid-January increase southward from $1.5 \mathrm{~mol} \mathrm{Cm}^{-2}$ at $55^{\circ} \mathrm{S}$ to $2.2 \mathrm{~mol} \mathrm{C} \mathrm{m}{ }^{-2}$ to $65^{\circ} \mathrm{S}$ across the Polar Frontal Zone (PFZ) into the AZ. (C) 2001 Elsevier Science Ltd. All rights reserved.

\section{Introduction}

This paper discusses the seasonal evolution of the hydrographic and biogeochemical properties of the Antarctic Polar Frontal Zone (PFZ) during the US Joint Global Ocean Flux (JGOFS) Antarctic Environment and Southern Ocean Process Study (AESOPS) in 1997-1998 (Smith et al., 2000). By virtue of its physical properties, the Antarctic Circumpolar Current (ACC) has a quite unique character for one of the ocean's most prominent circulation features. The eastward flow of the ACC is associated with a steep rise in isopycnals toward the south through the entire water column. Deacon (1937) noted that the poleward rise of isopycnals was not uniform but occurred in a series of clear step-like patterns or fronts. These steps (or regions of large horizontal density gradients) are associated with strong surface currents (Nowlin et al., 1997). These narrow jets are interspersed with zones of reduced or even reversed flow. The location of the US JGOFS ACC study region south of New Zealand along $170^{\circ} \mathrm{W}$ was selected based on the zonal orientation of the physical and chemical fronts found in that region. The fact that the zonal fonts are essentially parallel in the region minimizes the local effects of convergence and divergence. More importantly, the primary fronts are distinct and well separated from one another where in some sectors of the Southern Ocean the fronts merge, further complicating the physics and biogeochemistry. From north to south the frontal regions of interest include the Subantarctic Zone (SAZ), lying between the Subtropical Front (STF) and the Subantarctic Front (SAF); the Polar Front Zone (PFZ), located between the SAF and the Polar Front (PF); and the Southern ACC Front (SACCF) with the Antarctic Zone (AZ), encompassing all waters south of the PF (Whitworth, 1980; Orsi et al., 1995). Each of these is delineated by a number of variables, including temperature, salinity, and oxygen concentration, which characterize the classical zonation of the Southern Ocean. The locations of the principal fronts during the AESOPS study coincided with average positions reported by Orsi et al. (1995). Another important factor is that the PF is much further south than in the Atlantic and Indian sectors, thereby affecting the seasonal light supply, which should have consequences on the biological productivity. Finally, the Ross Gyre is present south of the ACC in this sector.

Smith et al. (2000) discuss the distribution of sea ice in 1997-98 along $170^{\circ} \mathrm{W}$. Sea ice covers most of the region south of the PF in winter. In general, the Seasonal Ice Zone (SIZ; Tréguer and Jacques, 1992) overlaps the AZ, and extends to ca. $62^{\circ} \mathrm{S}$, while the Permanently Open-Ocean Zone, defined as the region between the PF and the northern limits of sea ice (POOZ; Tréguer and 
Jacques, 1992) is virtually non-existent at $170^{\circ} \mathrm{W}$. While they overlap, the delineation between the SIZ and AZ is normally made on a biochemical basis; because the stabilizing effect of freshwater added by melting sea ice often leads to phytoplankton blooms as well as to distinct species assemblages (Smith and Nelson, 1985; Mitchell et al., 1991; Tréguer and Jacques, 1992; Arrigo et al., 1999). Smith et al. (2000) show that the SIZ extended north of $62^{\circ} \mathrm{S}$ in 1997 and 1998.

Most of the ACC is thought to be relatively unproductive (Jacques, 1989; Banse, 1996), although it is persistently replete in major nutrients. This renders the ACC as one of the most prominent High Nutrient Low Chlorophyll (HNLC) regions. Hoppema et al. (2000) point out that, in the South Atlantic sector, estimates of the total productivity of organic matter in the Antarctic are accordingly low, which would imply a rather low drawdown of carbon dioxide $\left(\mathrm{CO}_{2}\right)$ by phytoplankton production in this region. On the other hand, De Baar et al. (1995) pointed out that the PFZ is a unique oceanographic environment, exhibiting some of the highest phytoplankton biomass and primary productivity in the Southern Ocean. The PF separates the AZ to the south, where high winter silicate concentrations result from upwelling of Circumpolar Deep Water (CDW), from the PFZ to the north, where silicate-depleted Antarctic Intermediate Water (AAIW) sinks and begins its northward transit. As we will show, in the AESOPS data stratification in the AZ varies seasonally, and the biological response to summer stratification is evident in the reduction of nutrient concentrations and buildup of chlorophyll and POC.

Most of the previous studies in the ACC have been single cruises focused either on the physical oceanography or on the dramatic phytoplankton blooms characteristic of the austral spring. They typically describe conditions over one short time interval or derive temporal ("seasonal") change from data collected in different years and seasons. Herein we describe seasonal evolution of the hydrographic and biogeochemical (macronutrients, chlorophyll, POC and $\mathrm{CO}_{2}$ ) data observed along $170^{\circ} \mathrm{W}$ in 1997-1999 (Fig. 1). The station positions for the 4 JGOFS AESOPS ACC cruises are presented in Fig. 1. It is difficult using these data to separate the portion of the variability caused by changes in water masses associated with the strong zonal flow of the ACC and/or the variability of properties associated with the nutrient drawdown and recovery associated with the seasonal phytoplankton bloom. While we will show that the seasonal evolution of the properties is consistent with the seasonal biological cycle, it must be kept in mind that these data represent the seasonal variability at one location within a dynamic zonal current. To the extent that there is zonal uniformity between our sections, the temporal changes give some idea of the seasonal progression. Fortunately, previous studies have shown that, while the spatial variability within the ACC is extreme in the meridional sense with numerous fronts, there is some degree of zonal uniformity throughout the Southern Ocean.

This paper has been limited to a description of the seasonal evolution of the macronutrients, chlorophyll, POC, total carbon dioxide $\left(\mathrm{TCO}_{2}\right)$ and partial pressure of carbon dioxide $\left(\mathrm{pCO}_{2}\right)$ in the upper 400-m of the ACC in 1997-1998. We focus on the upper 400-m of the water column as the majority of the biogeochemical studies carried out during AESOPS were made on the upper $400 \mathrm{~m}$. The objective of this paper is to describe the basic frontal structure and water mass properties that hopefully will prove useful in interpreting the remainder of the biogeochemical measurements made during the AESOPS program. 


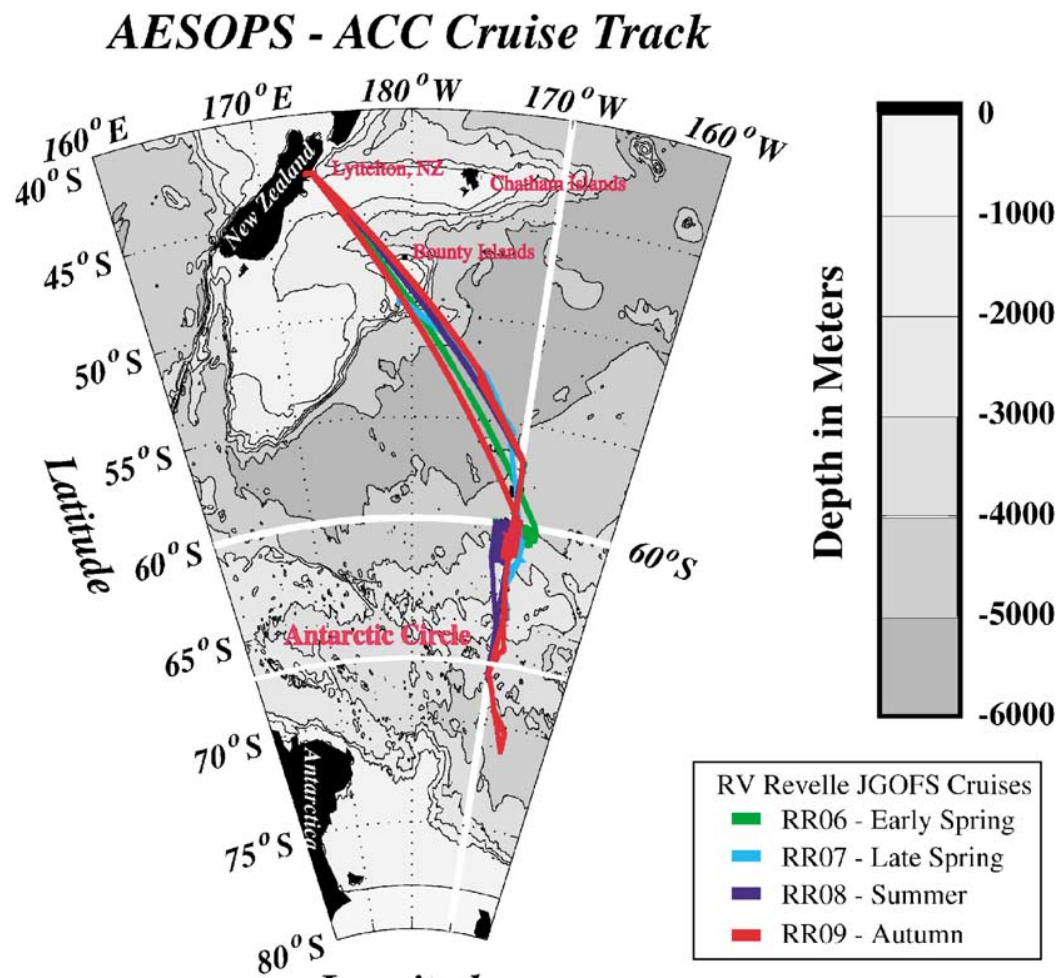

\section{Longitude}

Fig. 1. Station positions for the 4 JGOFS AESOPS ACC cruises: R06, R07, R08 and R09 overlaid on the bathymetry for the region. The positions of the AESOPS ACC sediment trap mooring are indicated by the large dots.

Table 1

US JGOFS AESOPS cruises to the Antarctic Circumpolar Current (ACC)

\begin{tabular}{lllll}
\hline Cruise & Purpose & Dates & Season & Ice pack \\
\hline R06 & PFZ survey I & $10 / 20 / 97-11 / 24 / 97$ & Late winter & $\sim 63^{\circ} \mathrm{S}$ \\
R07 & PFZ process I & $12 / 02 / 97-01 / 03 / 98$ & Spring & $\sim 67^{\circ} \mathrm{S}$ \\
R08 & PFZ survey II & $01 / 08 / 98-02 / 08 / 98$ & Summer & $>70^{\circ} \mathrm{S}$ \\
R09 & PFZ process II & $02 / 13 / 98-03 / 19 / 98$ & Autumn & $>72^{\circ} \mathrm{S}$ \\
\hline
\end{tabular}

\section{Data and methods}

\subsection{Seasonal coverage}

A total of 4 AESOPS cruises (Table 1) were made to the ACC aboard the $R / V$ Roger Revelle beginning in late austral winter, October/November 1997. The cruises took place in November/ 
December 1997 (austral spring), January/February1998 (austral summer) and February/March 1998 (austral fall), respectively. Two of the cruises were designated as "survey cruises", in that a strong emphasis was placed on the assessment of mesoscale variations in temperature, salinity, nutrients, $\mathrm{CO}_{2}$, particulate organic carbon (POC) and fluorescence within the region of the PF using a SeaSoar. The other two cruises were "process studies" where a variety of rate processes were measured, and the processes influencing carbon dynamics of the surface layer and vertical flux of particles were investigated in detail. Additional samples across the frontal regions were also collected as the RVIB Nathaniel B. Palmer transited the region to and from the Ross Sea. Palmer stations closely coincident in time along $\sim 170^{\circ} \mathrm{W}$ have been used in this study to extend the first Revelle section that was restricted by ice.

\subsection{CTD and hydrographic data}

All hydrographic data collected during the AESOPS ACC cruises used a dual temperature and conductivity sensor Sea-Bird (SBE) Conductivity-Temperature-Depth (CTD) system interfaced to a SBE Carousel Water Sampler, Chelsea Fluorometer and SeaTech and/or WebLab Transmissometer. All of the pressure and temperature measurements are from the CTD. Sampling for bottle salinity, nitrate $\left(\mathrm{NO}_{3}^{-}\right)$, nitrite $\left(\mathrm{NO}_{2}^{-}\right)$, ammonia $\left(\mathrm{NH}_{4}^{+}\right)$, phosphate $\left(\mathrm{PO}_{4}^{-3}\right)$, silicate $\left(\mathrm{SiO}(\mathrm{OH})_{3}^{-}\right), \mathrm{POC}$, chlorophyll, $\mathrm{TCO}_{2}$ and $\mathrm{pCO}_{2}$ employed 24 10-liter Bullister bottles (similar to Niskin bottles) mounted on the SBE Carousel. The calibrated and quality controlled data are all available from the US JGOFS Data Archive at the Woods Hole Oceanographic Institution (http://usjgofs.whoi.edu). For consistency, measurement protocols were strictly followed during the entire study, or in the case of $\mathrm{CO}_{2}$ measurements, certified reference materials were used to calibrate differences in procedure.

The sampling and analytical methods used for processing and reduction of the CTD and macronutrients were essentially those described in the JGOFS (SCOR, 1996) and WOCE WHP 91-1 (WHP Office, 1993) Protocols. Minor differences are noted in the Methodology ("Readme") files stored with the data. The JGOFS protocols do not describe an automated technique for the analysis of ammonium concentrations. We employed the Berthelot reaction using a method somewhat similar to the method described by Whitledge et al. (1981).

The Chelsea fluorometer was calibrated to fluorometric chlorophyll (fCHL; $\mathrm{mg} \mathrm{fCHL} \mathrm{m}^{-3}$ ) using bottle samples in which the chlorophyll content was determined using a Turner fluorometer. More information on the quality of the fluorometer data is given in the CTD documentation files in the JGOFS data archives (http://usjgofs.whoi.edu).

Beam attenuation coefficients were determined using SeaTech transmissometers $(\lambda=660 \mathrm{~nm}$, pathlength $=20 \mathrm{~cm}$ ). During R09 (Process II), a WetLabs transmissometer $(\lambda=660$, pathlength $=25 \mathrm{~cm}$ ) was also interfaced with the CTD from station 9 onward. Cross correlations showed that beam attenuation from the two instruments tracked very well throughout the water column, but the WetLabs signal was steadier in the mixed layer so these data were used in determining POC distributions. Regressions of POC and beam attenuation due to particles are given in the JGOFS data documentation (http://usjgofs.whoi.edu) and in Gardner et al. (1999). The POC distribution as determined by beam attenuation will be used in this paper.

Two different groups carried out $\mathrm{CO}_{2}$ measurements during the PFZ cruises. The $\mathrm{CO}_{2}$ system used during the R06 (Survey I) and R07 (Process I) was supplied by Frank Millero of the 
Rosentiel School of Marine and Atmospheric Sciences, University of Miami with methods similar to that of Millero et al. (1999). The $\mathrm{CO}_{2}$ system used during R08 (Survey II) and R09 (Process II) was supplied by Taro Takahashi from the Lamont-Doherty Earth Observatory (LDEO) with methods similar to that described in Chipman et al. (1993). For more information on these methods, check the data documentation at the JGOFS (http://usjgofs. whoi.edu). In addition, $\mathrm{CO}_{2}$ observations collected by LDEO using a continuously recording underway, uncontaminated pumping system aboard the Palmer during AESOPS and during the pre- and post-AESOPS period, as well as ROAVERRS (Research on Ocean-Atmosphere Variability and Ecosystem Response in the Ross Sea) programs, during a five-year period, 1995-2000, are combined to discuss seasonal changes in $\mathrm{CO}_{2}$ across the ACC.

\subsection{Construction of vertical sections}

The disparate nature of the cruises (Survey and Process cruises) led to a non-uniform geographic/temporal distribution of the data (i.e., there was a considerable number of repeat stations, as well as multiple casts at each of these stations, occupied at or near the fronts, with sparse data in other portions of the sections. This led to considerable effort being spent in construction of vertical sections that would be representative of the entire dataset on each of the cruises. First, stations within $5 \mathrm{~km}$ of each other were grouped together. The data from each station grouping were then averaged over $10-\mathrm{m}$ intervals to $250-\mathrm{m}$ and $20-\mathrm{m}$ intervals to $400-\mathrm{m}$ depth. Depth ranges that were missing data were filled in by vertical and/or horizontal linear interpolation between ranges that did contain data. The resultant gridded data set was then contoured. (Note that, if data were missing in the shallow depth ranges, then these data points were simply made equal to the first depth range that did contain data.)

In addition to vertical sections of properties, vertical sections of how the properties change from a reference vertical section (in this case, R06; Table 1) that was occupied in late winter before the spring phytoplankton bloom were constructed. To obtain a more comprehensive winter plot, single stations from JGOFS Ross Sea cruises that transited along $170^{\circ} \mathrm{W}$ aboard the RVIB Palmer at approximately the same time this section was occupied during JGOFS ACC cruise R06 were "spliced" onto the R06 section. This included one cast from NBP96-4 (cast 96400101 - JGOFS Event Number 09060104) and one cast from NBP96-4A (cast 96410103-JGOFS Event Number 10080643). These casts may be obtained from the JGOFS data archives at the Woods Hole Oceanographic Institution (http://usjgofs.whoi.edu). These data were "spliced" onto the southern end of the R06 section (R06plus) to extend the section to $64.72^{\circ} \mathrm{S}$ (southernmost cast on R07 so that the greatest common areal coverage could be displayed). The method of "splicing" entailed "extrapolation" of the data on each section to an endpoint at $64.72^{\circ} \mathrm{S}$ (normally this was just a trivial distance and as this extrapolation was done linearly it should have little or no effect on the calculation of section differences).

The vertical sections for cruise R07, R08 and R09 were subtracted from the reference vertical section (R06plus) to construct sections of "apparent drawdown" for the macronutrients. In addition, vertical sections of the change in fCHL, POC, and $\mathrm{TCO}_{2}$ over time were also constructed. Here the reference vertical section (R06plus) was subtracted from the vertical sections for cruise R07, R08 and R09 to construct "difference" plots, i.e., the sign of the difference plots is opposite that the drawndown plots. 


\section{Results and discussion}

\subsection{Water mass properties across the $A C C$}

Potential temperature $(\theta)$ versus salinity $(S)$ diagrams for the full depth of the deepest cast at each station location on cruises R06, R07, R08 and R09 are presented in Fig. 2 in order to present a complete picture of the observed meridional water mass variability across the ACC along $170^{\circ} \mathrm{W}$. The curves are color coded to represent stations taken in the SAZ, PFZ and AZ. These plots can be used not only to look at the water mass variability across the frontal systems, but also to see the deep-water mass structure of the $\mathrm{ACC}$ at $170^{\circ} \mathrm{W}$ (the remainder of the data discussion will focus on the upper $400 \mathrm{~m}$ ). The large meridional variability in properties associated with the various frontal zones and water masses present within the ACC south of New Zealand is readily observed, but the plots are not as useful to look at the zonal homogeneity of the ACC as not all of the sections made encompass the same meridional breath. The positions of the various water mass cores located at the section also identified on the plots. These include Antarctic Surface Water (AASW), Subantarctic Surface Water (SASW), AAIW, CDW and North Atlantic Deep Water (NADW).

\subsection{Fronts, zones and water masses}

The contoured vertical sections of potential temperature, salinity and fluorescence chlorophyll for R06, R07, R08 and R09 are used to define the frontal structure and infer the accumulation of phytoplankton biomass within the ACC at $170^{\circ} \mathrm{W}$ at the time of the AESOPS cruises. These sections were constructed using CTD data. For ease in comparing the sections, they are coregistered by the heavy black vertical line marking the position of $60^{\circ} \mathrm{S}$, which as we will see is the nominal subsurface position of the PF. Finally, the water masses present on these vertical sections are indicated on the potential temperature and salinity sections.

\subsubsection{Potential temperature}

The contoured vertical sections of potential temperature for R06, R07, R08 and R09 are shown in Fig. 3. The observed positions of the PF, SAF, and SACCF are also indicated. The PF is associated with the northernmost penetration of the $2^{\circ} \mathrm{C}$ isotherm (Orsi et al., 1995). The SAF is identified by the southernmost penetration of the $4-5^{\circ} \mathrm{C}$ isotherm at $400 \mathrm{~m}$ (Orsi et al., 1995). The SACCF is associated with the northern extent of the $-1.5^{\circ} \mathrm{C}$ temperature minimum (Read et al., 1995). The frontal positions agreed well with the high-velocity current jets seen by the ADCP (Barth et al., 2001). Finally, the subsurface temperature minimum found south of the PF is associated with the presence of AASW, while the surface temperature maximum located north of the SAF is associated with SASW. As expected, these sections look similar, since there is a good degree of zonal regularity throughout the Southern Ocean. Most of the variability in the upper layers is associated with the seasonal progression in mixed-layer depth (to be discussed later).

\subsubsection{Salinity}

The contoured vertical sections of salinity for R06, R07, R08 and R09 are shown in Fig. 4. The most obvious feature observed on these sections is the diving of the isohalines within the SASW in 
Salinity

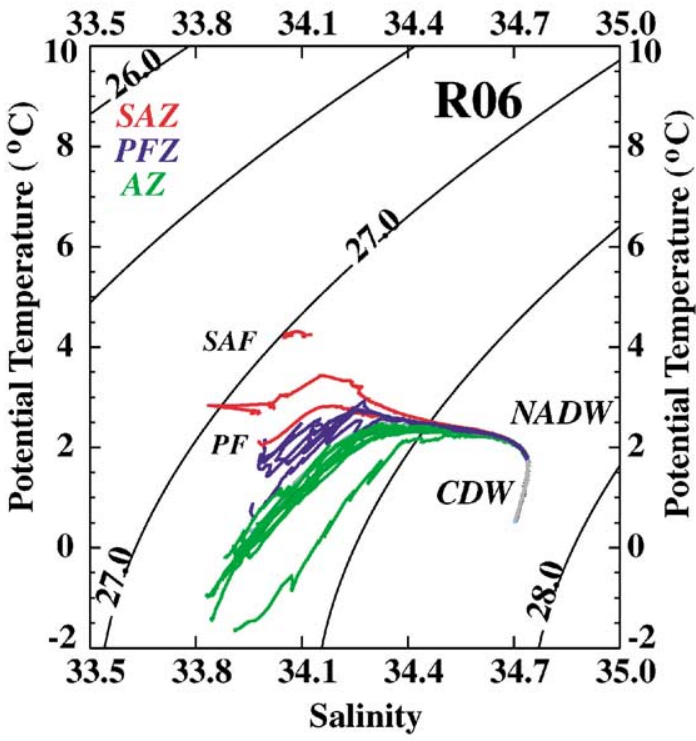

Salinity

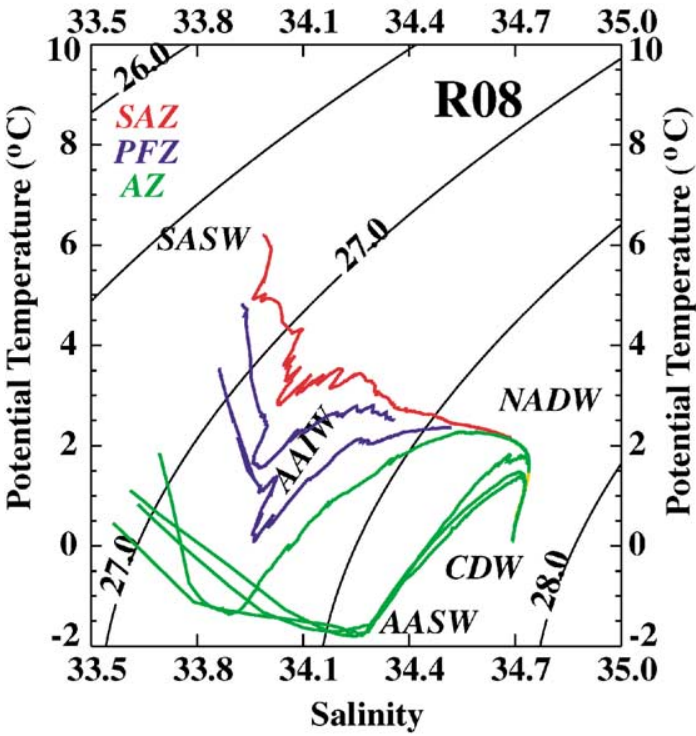

Salinity

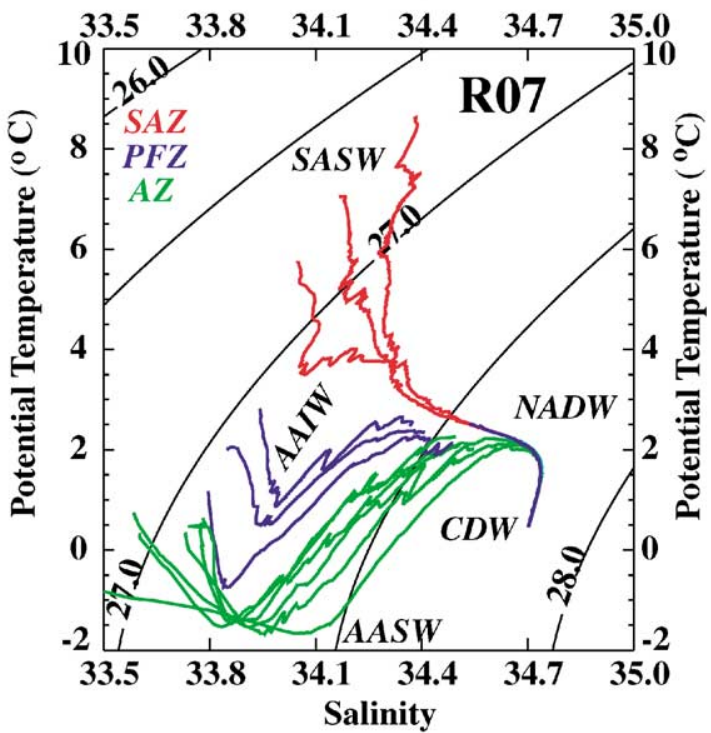

Salinity

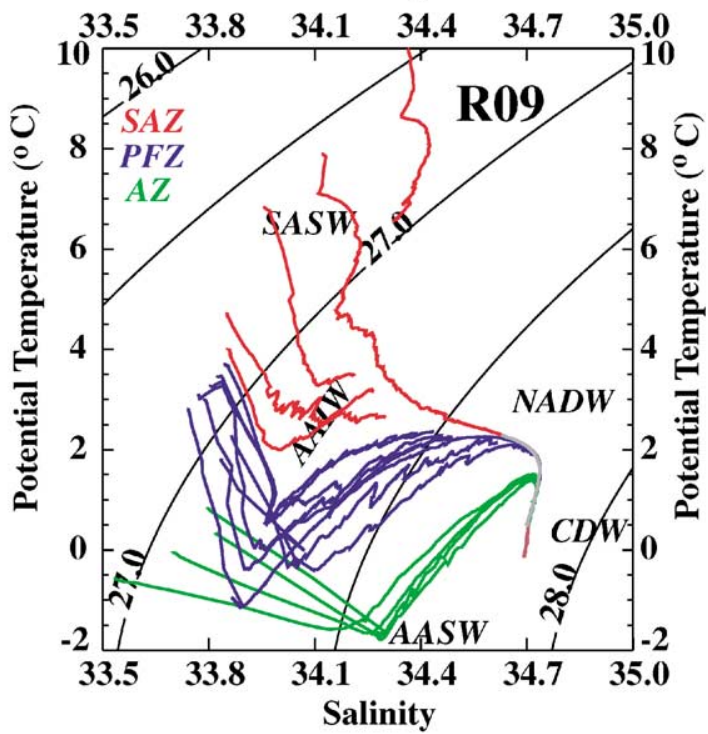

Fig. 2. Potential temperature $\left({ }^{\circ} \mathrm{C}\right)$ versus salinity for the deepest cast at each station location for the data collected during R06, R07, R08 and R09. The curves are color coded to indicate ACC zone where the station was occupied. The light curves are potential density anomaly $\sigma_{\theta}\left(\mathrm{kg} \mathrm{m}^{-3}\right)$ isopycnals.

the vicinity of the PF to form the subsurface salinity minimum associated with AAIW. Also, south of the PF beneath the AASW, the warm and saline waters of the CDW are observed. CDW is generally divided into Upper Circumpolar Deep Water (UCDW), characterized by low oxygen and high nutrients, and Lower Circumpolar Deep Water, characterized by higher salinities. While 

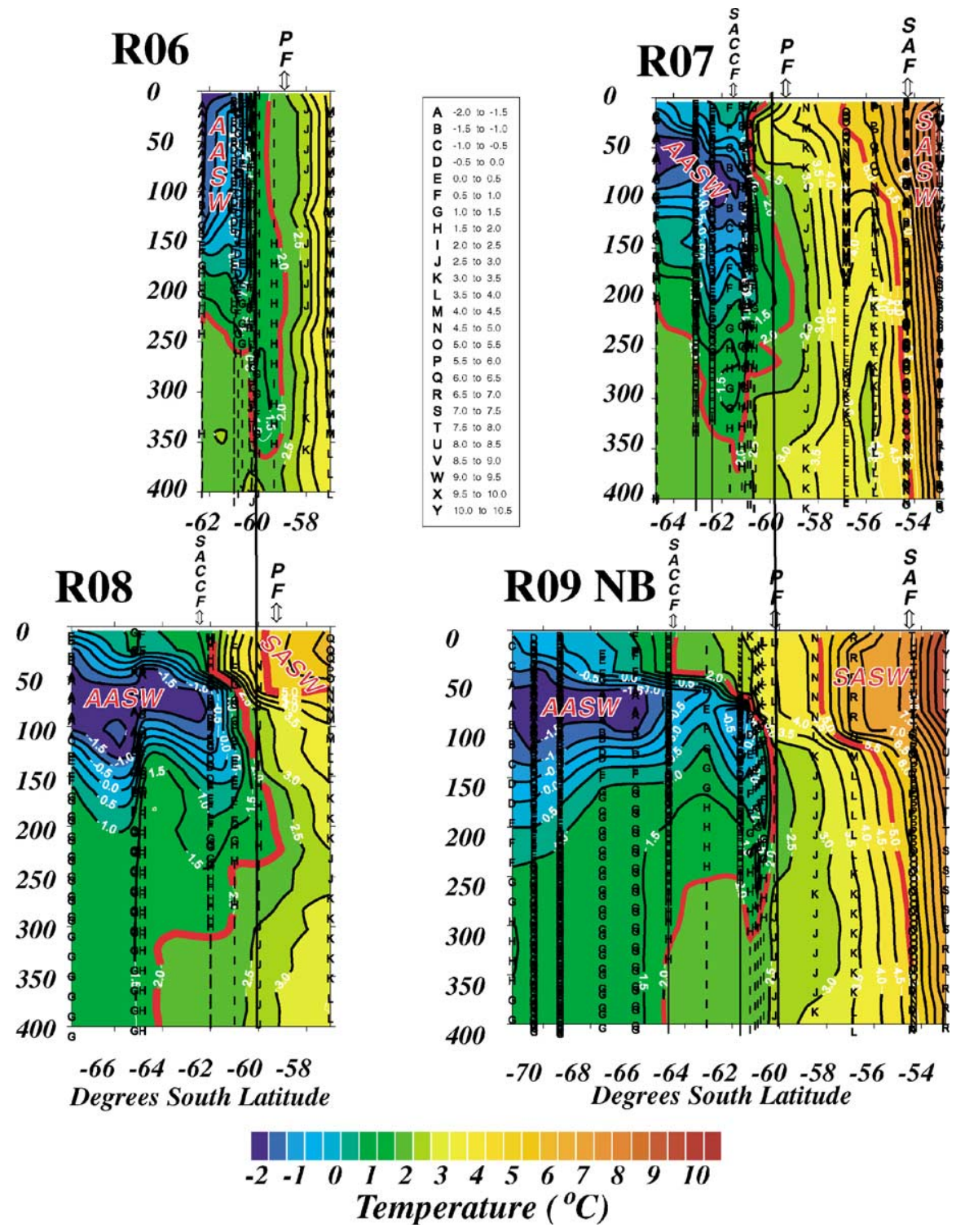

Fig. 3. The contoured vertical sections of potential temperatures $\left({ }^{\circ} \mathrm{C}\right)$ for R06, R07, R08 and R09. For ease in comparing the sections, they are co-registered by the heavy black vertical line marking the position of $60^{\circ} \mathrm{S}$, the nominal position of the $\mathrm{PF}$. The $2^{\circ} \mathrm{C}$ and $5^{\circ} \mathrm{C}$ isotherms are highlighted to aid in the identification of the fronts. The positions of the $\mathrm{PF}$ (northernmost penetration of the $2^{\circ} \mathrm{C}$ isotherm), the SAF (southernmost penetration of the $4-5^{\circ} \mathrm{C}$ isotherm at $400 \mathrm{~m}$ ), and the SACCF (northern extent of the $-1.5^{\circ} \mathrm{C}$ temperature minimum) are also indicated along the top axis of each section. (For reference the interpolated data field is overlaid on the sections.)

it is difficult to identify the location of the SACCF in this data suite, a doming in the isohalines is apparent at $\sim 63^{\circ} \mathrm{S}$ which is associated with a meander in the SACCF as shown in the ADCP velocities (Barth et al., 2001). 

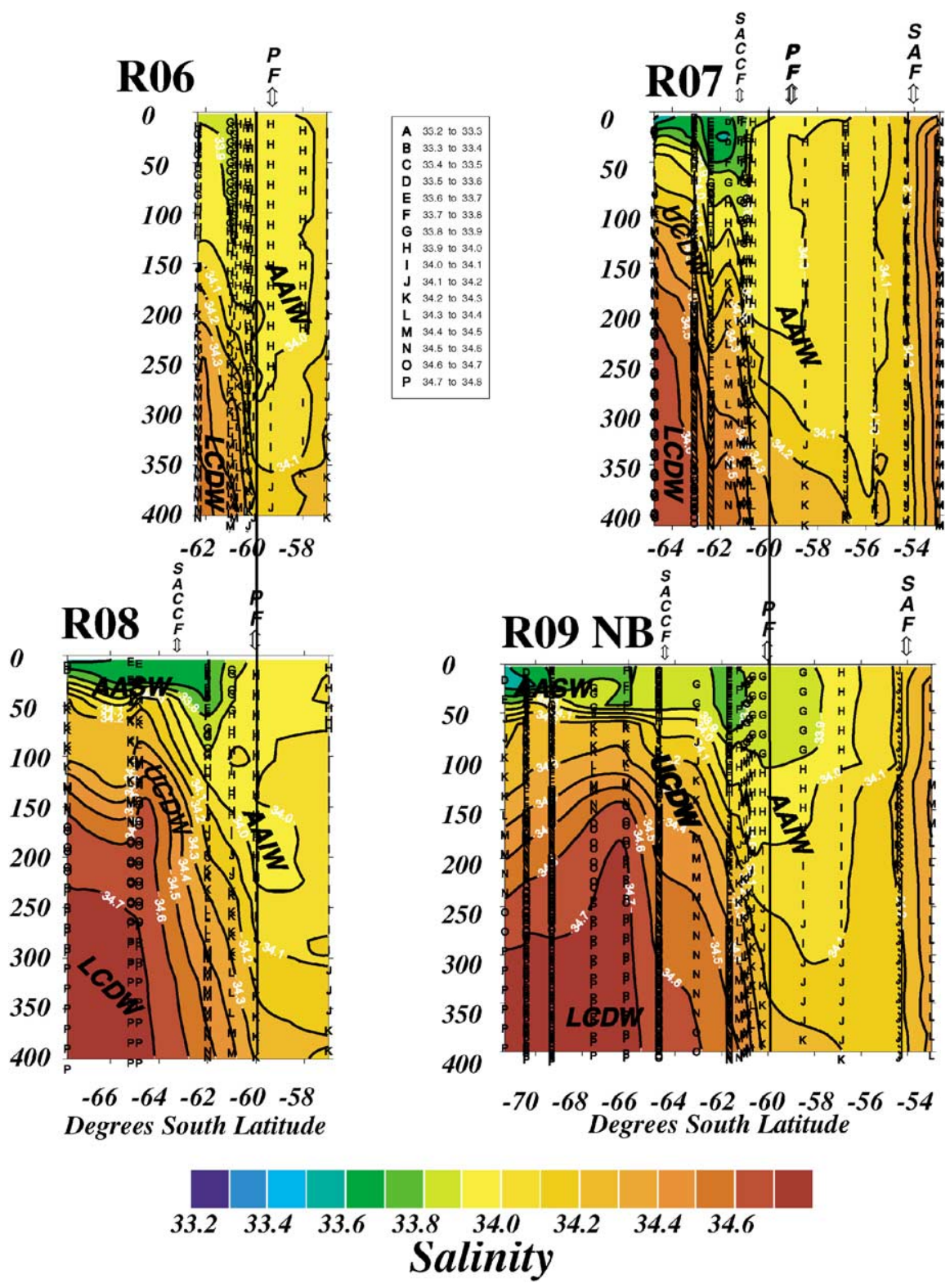

Fig. 4. Same as Fig. 3 except for salinity.

\subsubsection{Fluorescence chlorophyll ( $f C H L)$}

The vertical sections of $f C H L$ for R06, R07, R08 and R09 are shown in Fig. 5. As these sections were constructed using all the casts at every station, the normal diurnal changes in fCHL have been minimized. These sections indicate little or no fCHL below $\sim 150 \mathrm{~m}$, i.e., below the euphotic zone. In the late winter at the time of R06, weak evidence is seen for the presence of photosynthetic material in the $\mathrm{AZ}$ south of the $\mathrm{PF}$ along the retreating ice edge at the extreme 


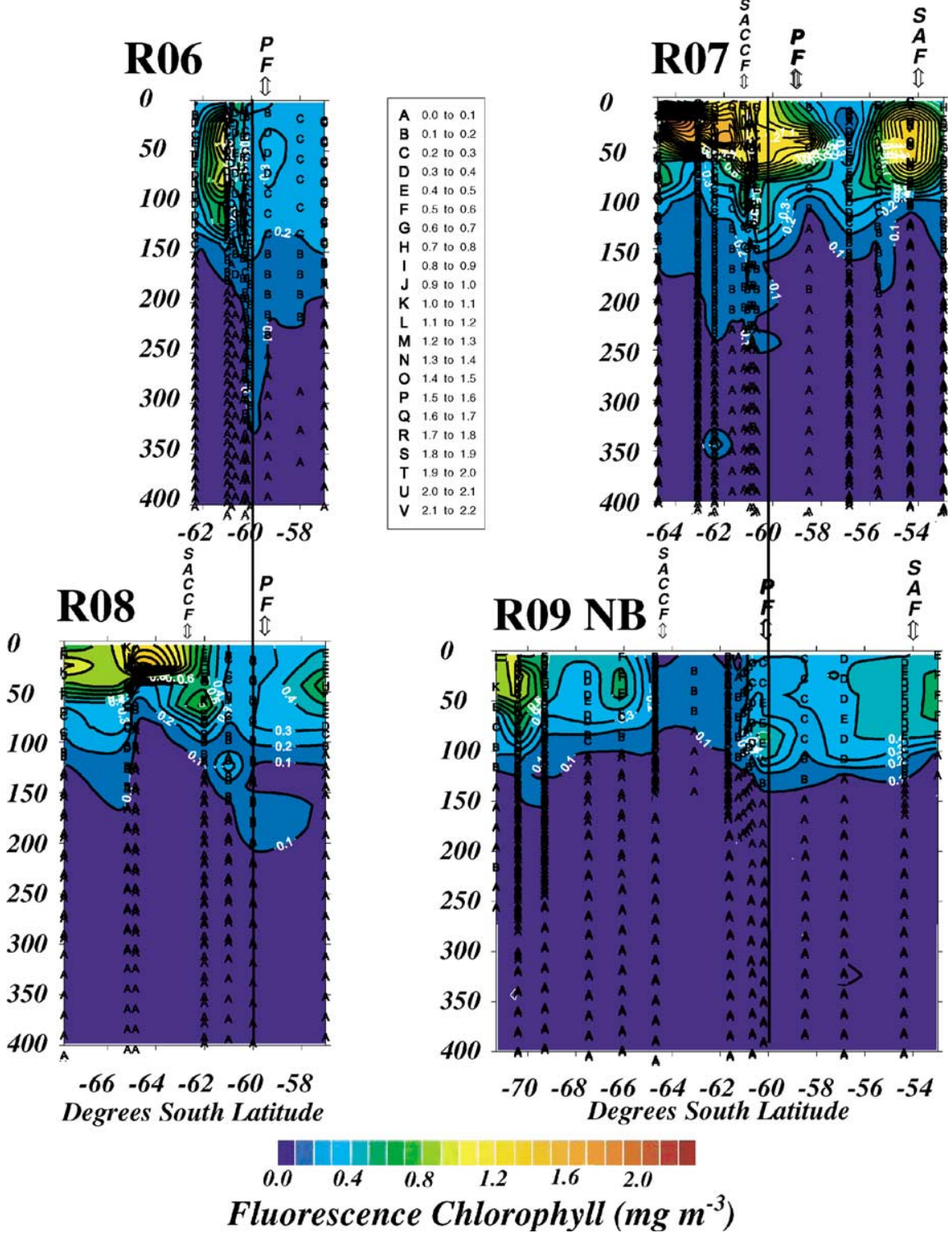

Fig. 5. Same as Fig. 3 except for fluorescence chlorophyll $\left(\mathrm{mg} \mathrm{fCHL} \mathrm{m}{ }^{-3}\right)$.

southern end of the section where fluorescence reached $>1.0 \mathrm{mg} \mathrm{fCHL} \mathrm{m}^{-3}$. In contrast, no significant enhancement of phytoplankton biomass was found in the vicinity of the retreating ice cover in the Atlantic sector by Smetacek et al. (1997) where melt-water-influenced zones were indicated by low salinity, but chlorophyll concentrations averaged only $0.3 \mathrm{mg} \mathrm{fCHL} \mathrm{m}{ }^{-3}$ and barely increased during the spring. By early summer $(<3$ weeks later in December) during R07, a spring bloom is in progress with high fluorescence, in excess of $2.3 \mathrm{mg} \mathrm{fCHL} \mathrm{m}^{-3}$ within the AZ near the southern end of the section. This fluorescence maximum extends across the AZ and into 
the PFZ. A smaller fluorescence maximum is seen at $\sim 54^{\circ}$ within the SASW to the north of the PF. In the Atlantic sector (Smetacek et al., 1997) phytoplankton blooms developed in the region of the PF with concentrations ranging from 0.7 to $>4 \mathrm{mg} \mathrm{chl} a \mathrm{~m}^{-3}$. By mid-summer during the time of section R08, maximum chlorophyll values were reduced, but relatively high values remained at $\sim 64^{\circ} \mathrm{S}$. By the autumn at time of R09 in the mid-February-mid-March, fluorescence maxima are further reduced and the region of highest values is now found well to the south at $\sim 70^{\circ}$.

\subsection{Mixed-layer depth}

The seasonal evolution of the mixed-layer depth is presented in Fig. 6. As knowledge of the seasonal evolution of mixed layer depth is important in our discussion of the changes in the biogeochemical properties in the surface layer, a brief summary is presented here. The mixed-layer depths (change in potential density anomaly $\left(\Delta \sigma_{\theta}\right)=0.02 \mathrm{~kg} \mathrm{~m}^{-3}$ ) in the northern PFZ were in excess of $100 \mathrm{~m}$ at the time of R06 (late winter). No data were taken in the AZ during R06, but mixed-layer depths $>120 \mathrm{~m}$ are representative of the AZ during winter. Surface heating contributed to summer stratification across the entire ACC and the reduction of surface salinity by melting sea ice in the SIZ further contributed to increased stratification south of the PF. By spring (R07) mixed-layer depths had shoaled to $<40-50 \mathrm{~m}$ in both the AZ and PFZ and stayed there through mid-summer (R08). By the fall cruise (R09), mixed-layer depths north of the PF had begun to increase to $>75 \mathrm{~m}$, while in the AZ they varied from around $75 \mathrm{~m}$ near the PF to $\sim 25 \mathrm{~m}$ near $70^{\circ} \mathrm{S}$.

\subsection{Vertical sections of nutrient drawdown}

Here vertical sections of apparent drawdown of total inorganic nitrogen $\left(\mathrm{NO}_{3}^{-}+\mathrm{NO}_{2}^{-}+\mathrm{NH}_{4}^{+}\right)$, dissolved phosphate $\left(\mathrm{PO}_{4}^{-3}\right)$ and dissolved silicate $\left(\mathrm{SiO}(\mathrm{OH})_{3}^{-}\right)$, and changes in fCHL, POC, TCO

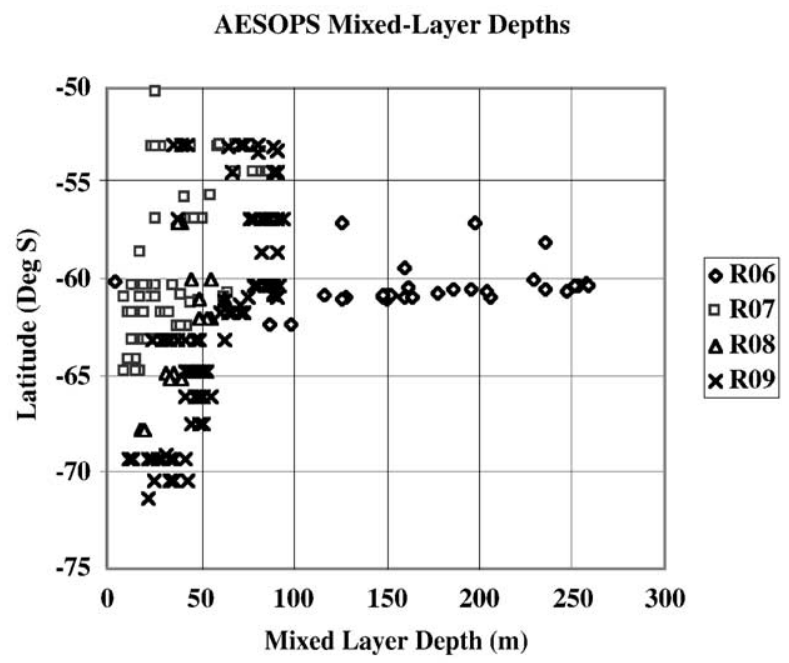

Fig. 6. The seasonal evolution of the mixed-layer depth $\left(\Delta \sigma_{\theta}=0.02\right.$ from the surface). 
and $\mathrm{pCO}_{2}$ are presented for commonly occupied portions of the transect though the ACC. Because of ice conditions, etc., even when the reference section is extended using data from the PALMER JGOFS cruises, the area of common coverage does not necessarily cover the entire region occupied on any particular cruise (e.g. see Fig. 2). Here we loosely define apparent nutrient drawdown as the change in nutrient concentrations from the reference section (R06plus) which extends to $64.72^{\circ} \mathrm{S}$ and was occupied during the late winter before the main phytoplankton bloom started, through the spring bloom, into the summer and finally during the fall. This does not take into account the fact that the data were collected in areas of strong zonal currents. Therefore, in addition to any drawdown due to biological activity, these drawdown plots also reflect any nonhomogeneity in the zonal distribution of water masses in the ACC and associated lateral and vertical mixing of different waters. Given the tendency for zonal uniformity in the water masses (see the salinity distribution below the surface layer, Fig. 4), we feel that the pre-bloom conditions represented in R06plus provide a useful "time-zero" starting point for estimating changes observed in the subsequent sections. The nutrients were not normalized by salinity. Inspection of the data in Fig. 2 shows that this does not change the results significantly. Unfortunately, the region of common data coverage for the 4 cruises did not extent far enough south to encompass all of the observed phytoplankton blooms (Smith et al., 2000), e.g., the ice edge bloom at $70^{\circ} \mathrm{S}$ on R09 (Fig. 5).

\subsubsection{Total inorganic nitrogen $\left(\mathrm{NO}_{3}^{-}+\mathrm{NO}_{2}^{-}+\mathrm{NH}_{4}^{+}\right)$drawdown}

The total inorganic nitrogen $\left(\mathrm{NO}_{3}^{-}+\mathrm{NO}_{2}^{-}+\mathrm{NH}_{4}^{+}\right)$distribution at the time of $\mathrm{R} 06$ plus and the subsequent changes in total inorganic nitrogen concentration during the seasonal phytoplankton bloom during the spring (R07), summer (R08) and into the fall (R09) are displayed in Fig. 7. The reference section, R06plus displays a doming of isopleths near $63^{\circ} \mathrm{S}$ that is associated with a meander in the SACCF as shown in the ADCP velocities (Barth et al., 2001). This meander, which has high nutrient UCDW at depths of $75-250 \mathrm{~m}$, has moved through the $170^{\circ} \mathrm{W}$ section by R07 which results in the apparent region of negative drawdown (i.e. increases) at depth of 75-250 $\mathrm{m}$ found south of $64^{\circ} \mathrm{S}$ during R07, R08 and R09. Other than this, the largest changes in total inorganic nitrogen concentrations occur within the mixed layer in the region between $64.72^{\circ} \mathrm{S}$ and the PF. The reference section (the extreme left panel) shows that at the time the ice began to retreat in late winter, the surface waters along this sections had concentrations ranging from a high of $>30 \mu \mathrm{mol} \mathrm{kg}^{-1}$ within the AASW south of the PF to $<24 \mu \mathrm{mol} \mathrm{kg}^{-1}$ north of the PF. During this period, mixed-layer depths were in excess of $120 \mathrm{~m}$. By the time of R07 (spring) the mixed-layer depths along the section had decreased to $\sim 40 \mathrm{~m}$. Within the mixed layer, there is evidence of significant drawdown reaching $\sim 7 \mu \mathrm{mol} \mathrm{kg}^{-1}$ by the time of $\mathrm{R} 07$ (spring) with a maximum drawdown of greater than $10 \mu \mathrm{mol} \mathrm{kg}^{-1}$ (approximately $30 \%$ of the available total inorganic nitrogen has been consumed) by R08 (summer) in the $40 \mathrm{~m}$ deep mixed layer. The drawdown of inorganic nitrogen decreased by about $3 \mu \mathrm{mol} \mathrm{kg}{ }^{-1}$ at the beginning of R09 (fall) and by another $2 \mu \mathrm{mol} \mathrm{kg} \mathrm{kg}^{-1}$ by the second leg of R09. This put the surface concentrations back to within $5 \mu \mathrm{mol} \mathrm{kg}^{-1}$ of their original concentrations by late fall when the mixed-layer depth had begun to deepen north of the PF. The data show that, even during the maximum period of the phytoplankton bloom in the early summer, the surface (euphotic zone) was replete with total inorganic nitrogen. Therefore, the phytoplankton bloom was not nitrogen limited. Below the euphotic zones, some of the changes can be related to changes in salinity due to factors such as the 

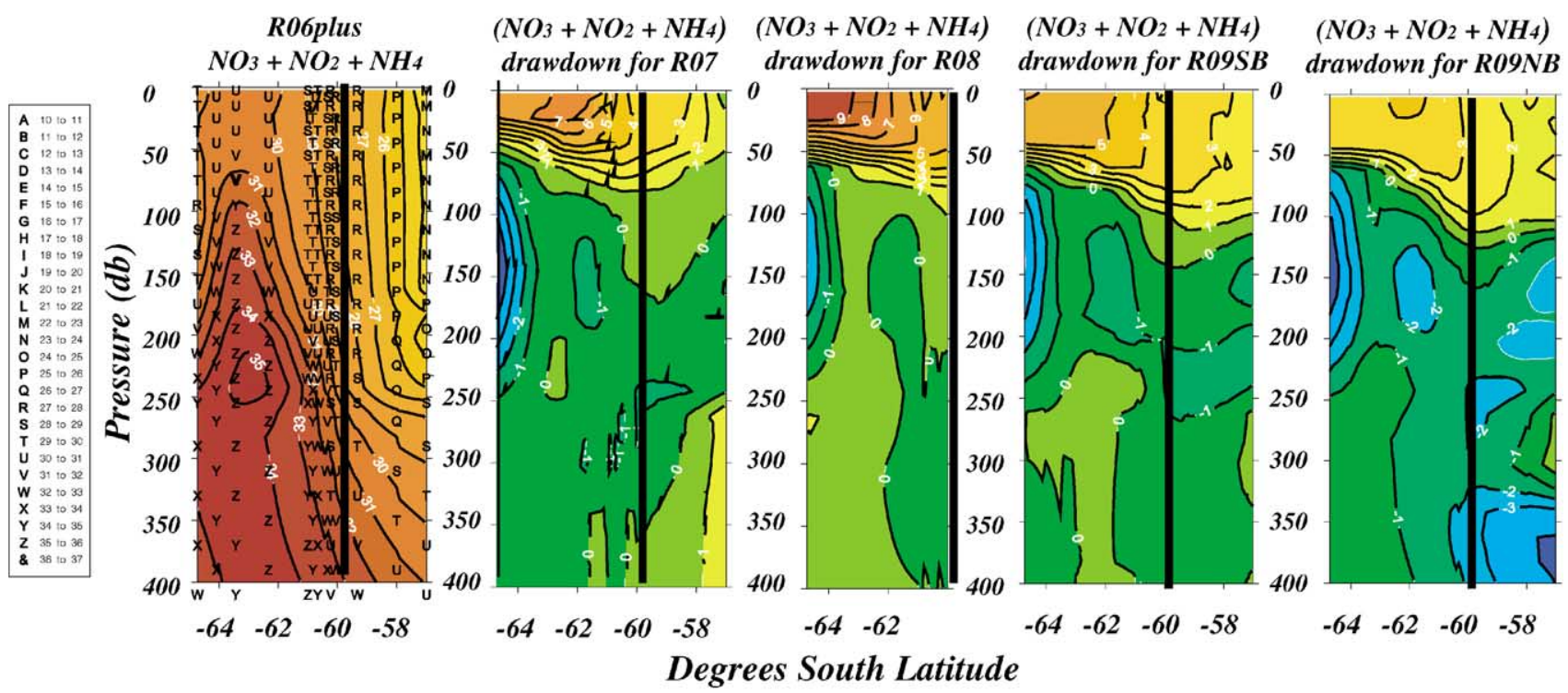

Original $\mathrm{NO}_{3}+\mathrm{NO}_{2}+\mathrm{NH}_{4}$ Concentrations in $\mathrm{umol}_{\mathrm{kg}}{ }^{-1}$

Drawdown of $\left(\mathrm{NO}_{3}+\mathrm{NO}_{2}+\mathrm{NH}_{4}\right)$ Concentrations in $\mu$ mol $\mathrm{kg}^{-1}$
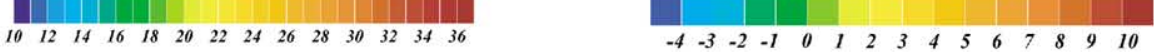

Fig. 7. Vertical section of total inorganic nitrogen $\left(\mathrm{NO}_{3}^{-}+\mathrm{NO}_{2}^{-}+\mathrm{NH}_{4}^{+}\right)$for the reference cruise R06plus (see text), and sections of "drawdown" (reference section R06plus - R07, R08 or R09) of total inorganic nitrogen for cruises R07, R08 and R09 (southbound (SB) and northbound (NB) sections are presented). For ease in comparing the sections, they are co-registered by the heavy black vertical line marking the position of $60^{\circ} \mathrm{S}$, the nominal position of the PF. (The interpolated data field is overlaid on the reference section.) 
meander mentioned above, but the more generalized subsurface increase during R09, may indicate net regeneration.

\subsubsection{Phosphate $\left(\mathrm{PO}_{4}^{-3}\right)$ drawdown}

The phosphate distribution during winter at the time of R06plus and the subsequent changes in phosphate concentration during the seasonal phytoplankton bloom during the spring (R07), summer (R08) and into the fall (R09) are displayed in Fig. 8. Once again the effects of the meander of the SACCF at approximately $63^{\circ} \mathrm{S}$ are observed on the reference section, as well as increased phosphate concentrations in UCDW leading to an apparent region of negative drawdown at depth of 75-250 m found south of $64^{\circ} \mathrm{S}$ during R07, R08 and R09. As was the case with total inorganic nitrogen, the most obvious changes in phosphate concentrations occur in the upper 50-75 $\mathrm{m}$ between the southernmost station and the PFZ. The reference section (the extreme left panel) shows that at the time the ice began to retreat in late winter, the surface waters along this sections has concentrations ranging from a high of $>2.1 \mu \mathrm{mol} \mathrm{kg} \mathrm{k}^{-1}$ within the AASW south of the PF to $1.7 \mu \mathrm{mol} \mathrm{kg}{ }^{-1}$ north of the PF. The region of significant drawdown was limited to the mixed layer during the spring and summer. Within the mixed layer significant drawdown is observed reaching $0.75 \mu \mathrm{mol} \mathrm{kg}^{-1}$ by the time of R07 (spring) and a maximum drawdown of $1.0 \mu \mathrm{mol} \mathrm{kg}^{-1}$ (approximately $50 \%$ of the available phosphate has been consumed) by $\mathrm{R} 08$ (summer). Dissolved phosphate increased by $0.3 \mu \mathrm{mol} \mathrm{kg} \mathrm{kg}^{-1}$ at the beginning of R09 (fall) and reached $0.5 \mu \mathrm{mol} \mathrm{kg}{ }^{-1}$ by the second leg of R09, thus increasing the surface concentrations back to within $0.3 \mu \mathrm{mol} \mathrm{kg}{ }^{-1}$ of the original winter concentrations. As was the case with nitrogen, even during the maximum period of the phytoplankton bloom in the early summer, the surface (euphotic zone) was replete with total phosphate. Therefore, at least on appearances of drawdown, the phytoplankton bloom was not phosphate limited.

Below the euphotic zone, all of the apparent drawdown sections show a slight increase in dissolved phosphate on the order of $0.1-0.2 \mu \mathrm{mol} \mathrm{kg}^{-1}$. This increase might reflect the changes in the water below the euphotic zone associated with changes in the water masses. If so, such a small increase once again suggests relatively uniform zonal water mass distributions in the ACC below the seasonal mixed layer.

\subsubsection{Dissolved silicate ( $\left.\mathrm{SiO}(\mathrm{OH})_{3}^{-}\right)$drawdown}

The silicate $\left(\mathrm{SiO}(\mathrm{OH})_{3}^{-}\right)$distribution in winter at the time of $\mathrm{R} 06$ plus and the subsequent changes in silicate concentration during the seasonal phytoplankton bloom during the spring (R07), summer (R08) and into the fall (R09) are displayed in Fig. 9. The effects of the meander of the SACCF at approximately $63^{\circ} \mathrm{S}$, while not obvious in the dissolved silicon distribution, result in an apparent region of negative drawdown at depth of $75-250 \mathrm{~m}$ found south of $64^{\circ} \mathrm{S}$ during R07, R08 and R09. The most obvious changes in silicate concentrations occur in the mixed layer in the spring and summer between the southernmost station and the PF, which is also the region of strong surface silicate gradients. The reference section shows that at the time the ice began to retreat in late winter, the surface waters along this section had concentrations ranging from a high of $>65 \mu \mathrm{mol} \mathrm{kg}{ }^{-1}$ within the AASW south of the PF to $<15 \mu \mathrm{mol} \mathrm{kg}^{-1}$ north of the PF, with a strong decreasing gradient in AZ. Within this surface layer, we see significant drawdown reaching $30 \mu \mathrm{mol} \mathrm{kg}{ }^{-1}$ by the time of R07 (spring), reaching a maximum drawdown of $40 \mu \mathrm{mol} \mathrm{kg} \mathrm{kg}^{-1}$ by $\mathrm{R} 08$ (summer). This maximum drawdown observed during the summer represents that $85-95 \%$ of the 


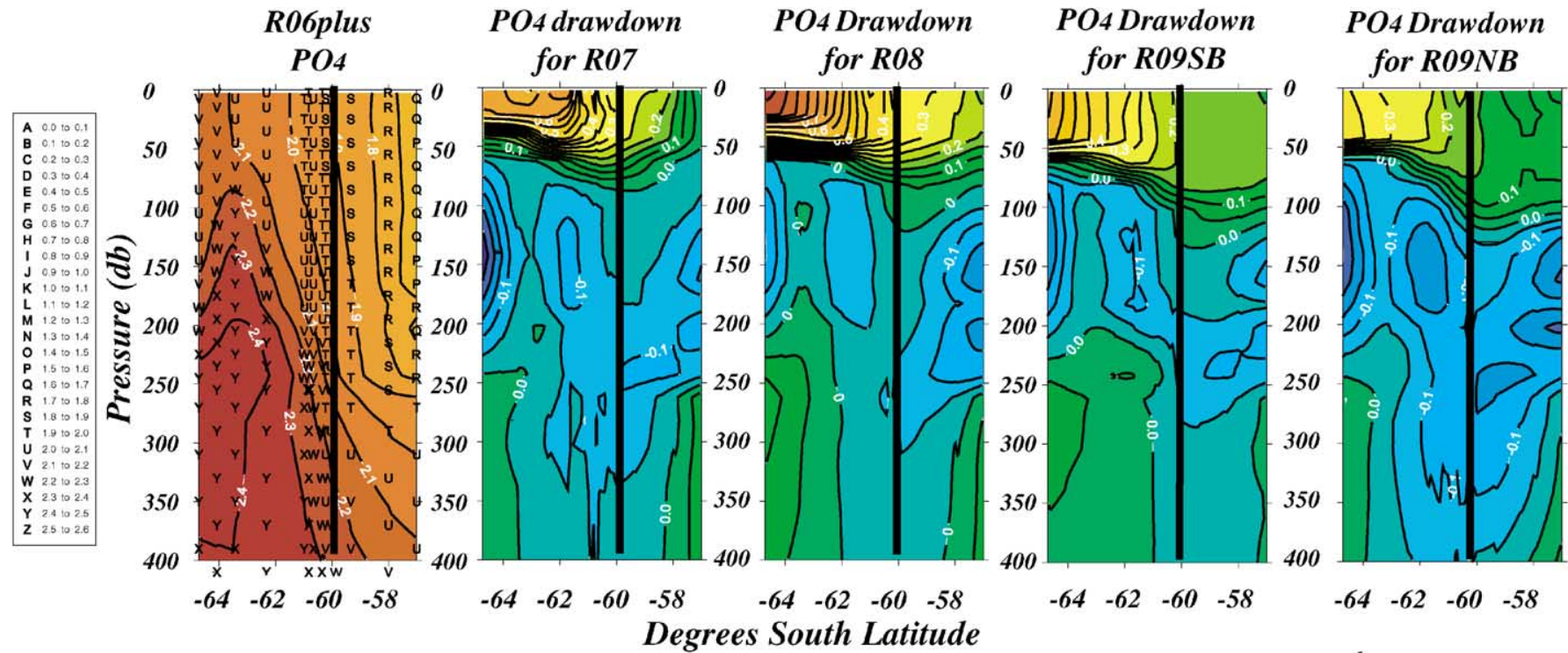

Original PO4 Concentrations in $\mu \mathrm{mol} \mathrm{kg}-\mathrm{I}$

$\begin{array}{llllllllllllll}0.0 & 0.2 & 0.4 & 0.6 & 0.8 & 1.0 & 1.2 & 1.4 & 1.6 & 1.8 & 2.0 & 2.2 & 2.4\end{array}$

Drawdown of PO4 Concentrations in $\mu \mathrm{mol} \mathrm{kg}^{-1}$

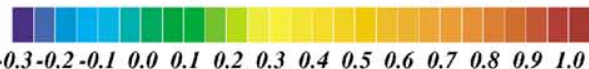

Fig. 8. The same as Fig. 7 except for dissolved phosphate $\left(\mathrm{PO}_{4}^{-3}\right.$ in $\left.\mu \mathrm{mol} \mathrm{kg}{ }^{-1}\right)$. 


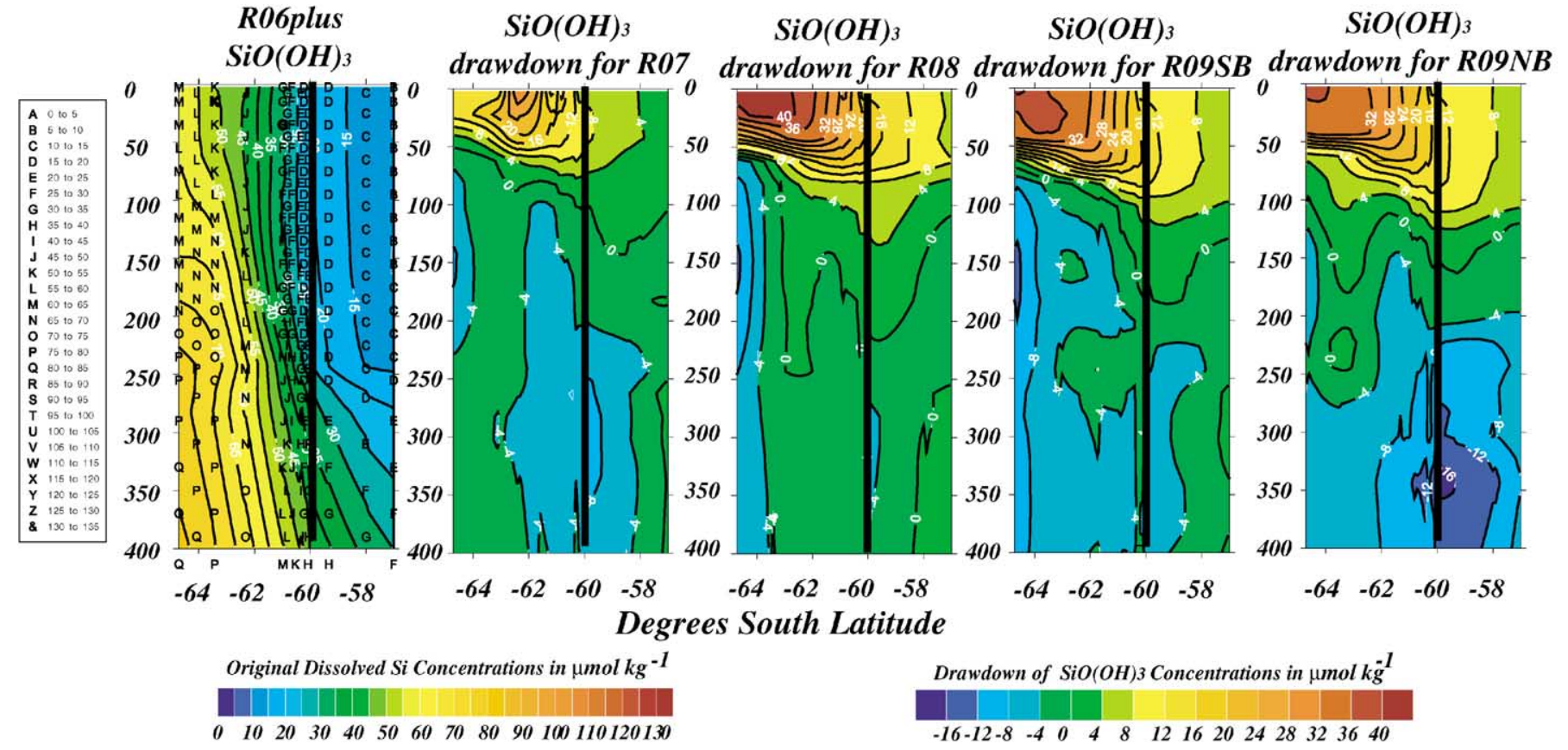

Fig. 9. The same as Fig. 7 except for dissolved silicate $\left(\mathrm{SiO}(\mathrm{OH})_{3}^{-}\right.$in $\left.\mu \mathrm{mol} \mathrm{kg}^{-1}\right)$. 
available silicate has been consumed. There is little change in silicate drawdown by the beginning of R09 (Fall) and while we still see silicate drawdowns in the order of $40 \mu \mathrm{mol} \mathrm{kg}{ }^{-1}$ by the time of the second leg of R09, the region of maximum silicate drawdown has become smaller and moved further south. Unlike the cases of nitrogen and phosphate, silicate was much closer to becoming depleted in the surface waters (euphotic zone) south of the PF by early summer (maximum period of the phytoplankton bloom) in the early summer and remained close to depletion throughout the summer and into the fall.

Below the euphotic zone, as was the case with inorganic nitrogen, there are strong gradients in dissolved silicate across the ACC as shown by the reference section, but the general increase to concentrations $>20 \mu \mathrm{mol} \mathrm{kg}{ }^{-1}$ above the reference section in the PFZ (north of $60^{\circ} \mathrm{S}$ ) most likely is an indication of regeneration. Inspection of the ratios of apparent nutrient drawdown near $64^{\circ} \mathrm{S}$ suggest $\mathrm{N} / \mathrm{P}$ apparent drawdowns to have a ratio of $\sim 10$ and $\mathrm{N} / \mathrm{Si}$ apparent drawdowns to have a ratio of $>4$. These ratios suggest a bloom that was dominated by Fe limited diatoms (e.g. Smith et al., 2000; Sweeney et al., 2000).

\subsection{Vertical sections of change in fCHL, $\mathrm{POC}, \mathrm{TCO}_{2}$ and $\mathrm{pCO}_{2}$}

Here vertical sections of apparent change in fCHL, $\mathrm{POC}, \mathrm{TCO}_{2}$ and $\mathrm{pCO}_{2}$ are presented for commonly occupied portions of the transect though the ACC. Once again the sections are referenced to section R06plus (see above) which extends to $64.72^{\circ} \mathrm{S}$ and was occupied during the late winter before the main phytoplankton bloom started, through the spring bloom, into the summer and finally during the fall. As was the case with the nutrients, these computations do not take into account the fact that the data were collected in areas of strong zonal currents. Therefore in addition to any changes due to biological activity, these plots also reflect non-homogeneity in the zonal distribution of water masses in the ACC and the effects of the mixing of different water masses and types. Given the tendency for zonal uniformity in the water masses (see the salinity distribution below the surface layer, Fig. 4), we feel that the pre-bloom conditions represented in R06plus provide a useful "time-zero" starting point for estimating changes observed in the subsequent sections. We did not normalize the $\mathrm{TCO}_{2}$ concentrations to a constant salinity.

\subsubsection{Fluorescence chlorophyll change}

We also tried to see if there were any apparent changes in phytoplankton population using fCHL as a surrogate. The fCHL distribution in winter at the time of R06plus and the subsequent changes in fCHL concentration during the seasonal phytoplankton bloom are presented in Fig. 10. (Here the reference vertical section (R06plus) was subtracted from the vertical sections for cruise R07, R08 and R09 to construct "difference" plots, i.e., the sign of the difference plots is opposite that the drawndown plots.) As expected, the only significant changes in fCHL occur in the euphotic zone, 100-150 m deep, but the maximum changes in fCHL occur within the mixed layer in a depth range where maximum nutrient drawdown was also observed. Within the euphotic zone, at the time of the reference section (R06plus), low fCHL concentrations $>0.2 \mathrm{mg}$ fCHL m ${ }^{-3}$ were found across the entire section, with a patch of high fCHL well south of the PF near $62^{\circ} \mathrm{S}$, with concentrations reaching in excess of $1.5 \mathrm{mg} \mathrm{fCHL} \mathrm{m}{ }^{-3}$. Recall from Fig. 5 that this was just the beginning of the bloom. Maximum concentrations and areal coverage by the bloom occurred at the time of R07 and R08, with a significant reduction by R09. This increase in fCHL is 


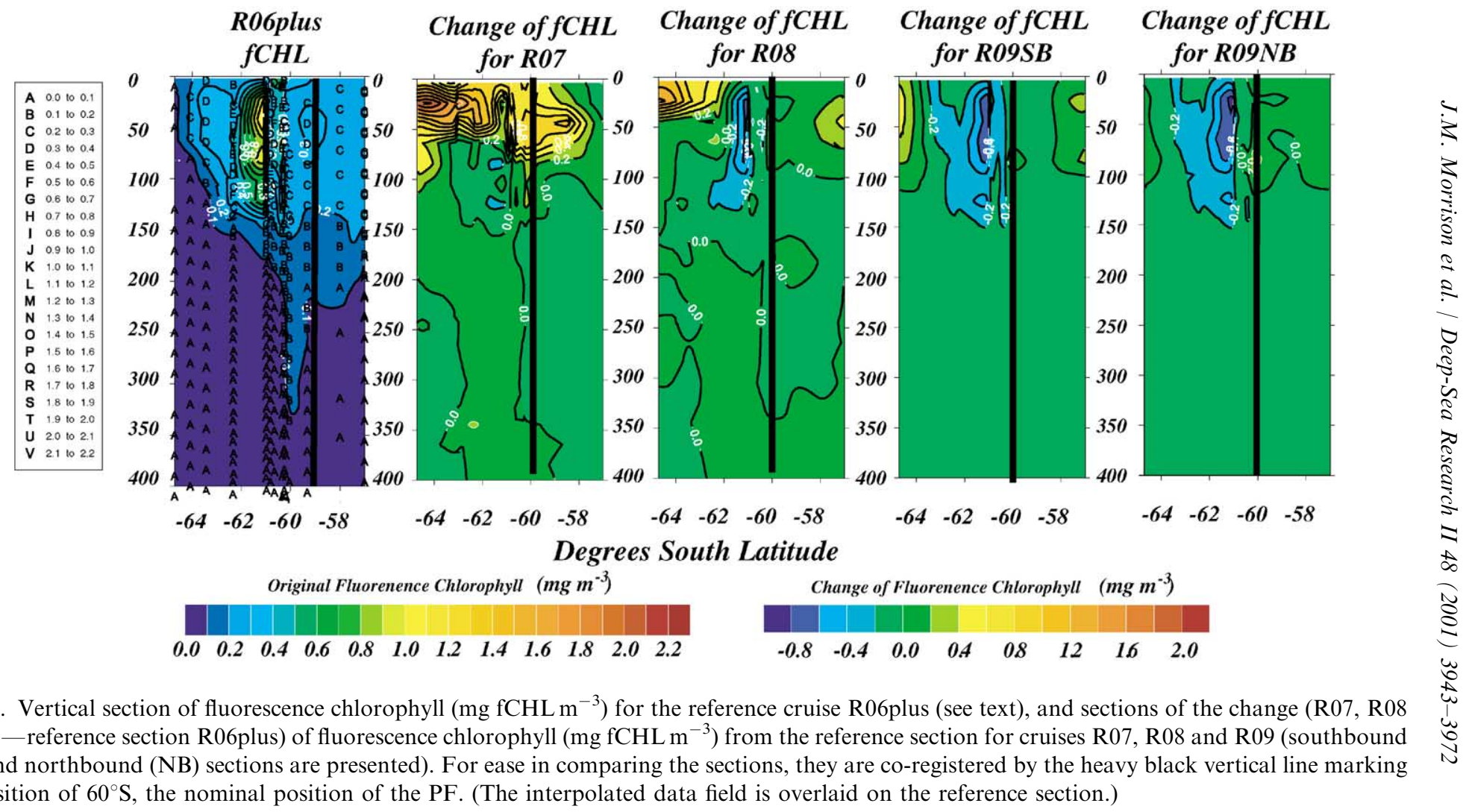


obvious in the difference between R06 and R07 (Fig. 10) in the patch south of the PF in AZ has increased by $>2.2 \mathrm{mg} \mathrm{fCHL} \mathrm{m}{ }^{-3}$ at $64^{\circ} \mathrm{S}$. There is some indication of a smaller bloom (concentrations $>1.5 \mathrm{mg} \mathrm{fCHL} \mathrm{m}{ }^{-3}$ ) at the PF. By the time of R07 (which coincides with the period of maximum fCHL in Fig. 5) the increase in fCHL has begun to reduce, with only a small region in the AZ $\left(\sim 64^{\circ} \mathrm{S}\right)$. Finally by the time of R09, we see a significant decrease in fCHL with an area where fCHL has actually decreased to below winter-time concentrations seen on R06 (difference of $\sim-0.08 \mathrm{mg} \mathrm{fCHL}{ }^{-3}$ ) as the phytoplankton bloom dies out. This is consistent with the nutrient drawdown plots where we saw maximum drawdown in the nutrients in the surface layer in the spring (R07), representing maximum utilization of the nutrients during the spring bloom. Drawdown decreased as the bloom began to die down in the summer (R08) and the nutrients returned to almost their original concentrations by fall (R09).

\subsubsection{Particulate organic carbon (POC) change}

The POC distribution at the time of R06plus and the subsequent changes in POC during the seasonal phytoplankton bloom during the spring (R07), summer (R08) and into the fall (R09) are displayed in Fig. 11. The changes in POC mimic those of fCHL with most changes occurring in the upper $50 \mathrm{~m}$, which might be expected, as POC is a byproduct of biological activity. An increase in POC concentrations in excess of $20 \mu \mathrm{mol} \mathrm{C} \mathrm{kg}^{-1}$ is observed south of the PF in the AZ by the spring (R07) and increased to in excess of $25 \mu \mathrm{mol} \mathrm{C} \mathrm{kg}^{-1}$ by the summer (R08). By the fall cruise (R09), the net change in POC from the winter had dropped to $<10 \mu \mathrm{mol} \mathrm{C} \mathrm{kg}^{-1}$ by the beginning of R09 and back to essentially pre-bloom conditions by the end of R09.

\subsubsection{Total carbon dioxide $\left(\mathrm{TCO}_{2}\right)$ change}

The $\mathrm{TCO}_{2}$ distribution at the time of R06plus and the subsequent changes in $\mathrm{TCO}_{2}$ concentration during the seasonal phytoplankton bloom during the spring (R07), summer (R08) and into the fall (R09) are displayed in Fig. 12. $\mathrm{TCO}_{2}$ in seawater is altered by a number of oceanographic processes including the biological utilization/respiration, production/dissolution of calcareous organisms, sea-air gas exchange, water mass mixing and water balance (evaporation/ precipitation and ice formation/melting). For this reason, it is difficult to isolate the contributions from each of these processes. The changes presented in Fig. 12 reflect the composite effects of all these processes, and deconvolution of the observed $\mathrm{TCO}_{2}$ changes into various processes is outside of the present paper. In the mixed layer, we observe that by the summer cruise (R08), $\mathrm{TCO}_{2}$ concentration has decreased by $\sim 40 \mu \mathrm{mol} \mathrm{kg}{ }^{-1}$, with maximum reduction within the AZ in excess of $80 \mu \mathrm{mol} \mathrm{kg}{ }^{-1}$. These changes are broadly consistent with the estimates for the biological utilization that will be presented in Table 2. Hence, the seasonal changes in $\mathrm{TCO}_{2}$ observed in mixed layer waters during the late winter through mid-summer are primarily a result of biological drawdown. By the fall (R09), the surface layer south AZ has begun to return to the winter concentrations.

\subsection{Seasonal variation of $\mathrm{pCO}_{2}$ in surface waters and sea-air $\mathrm{CO}_{2}$ flux over the $\mathrm{ACC}$}

Figs. 13 and 14 show the seasonal variation of SST and $\mathrm{pCO}_{2}$ in the surface waters in the vicinity of the PF observed continuously using the underway, uncontaminated pumping system. The measurements obtained during a five-year period, 1995-2000, are plotted as a function of 


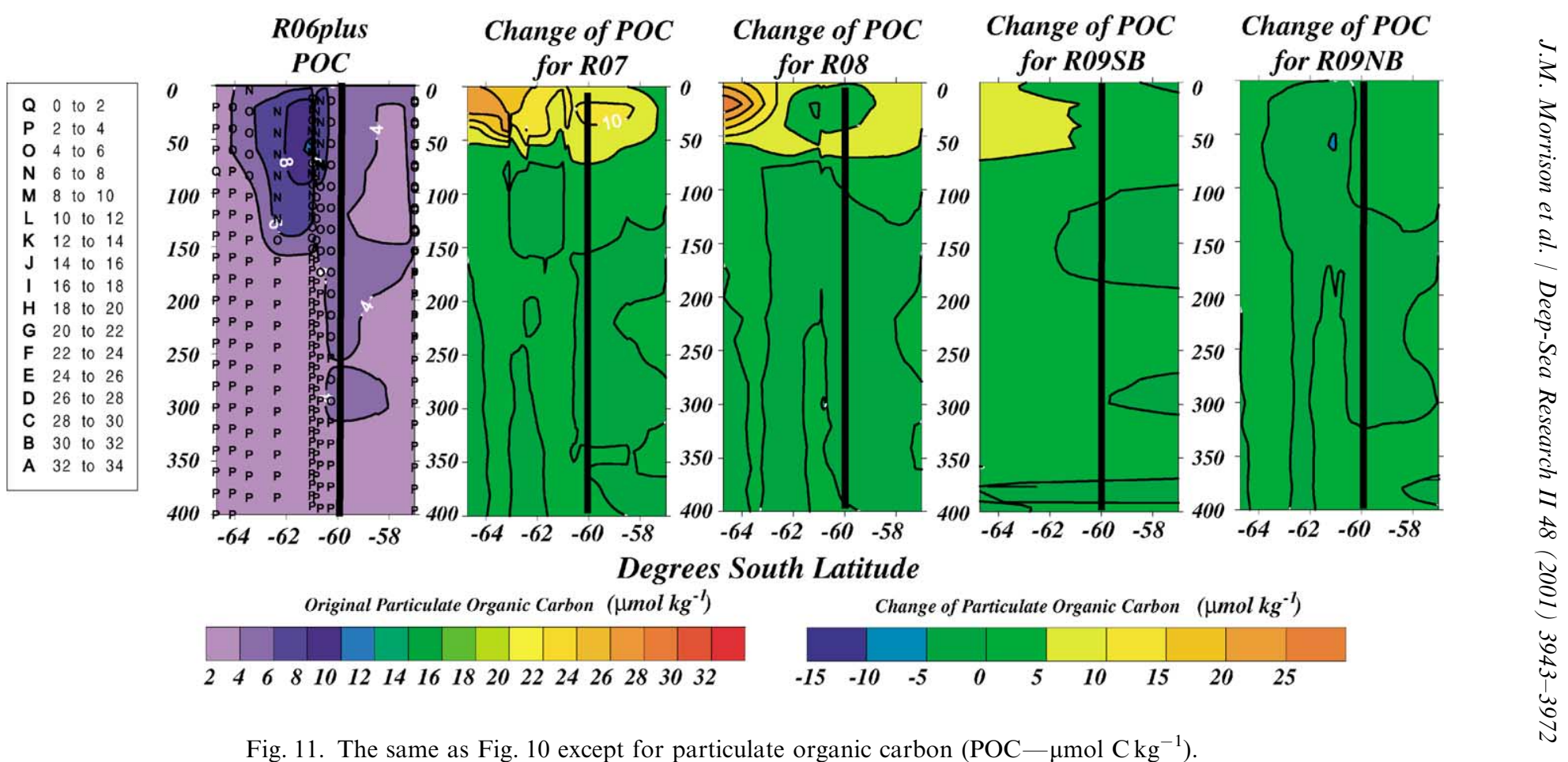




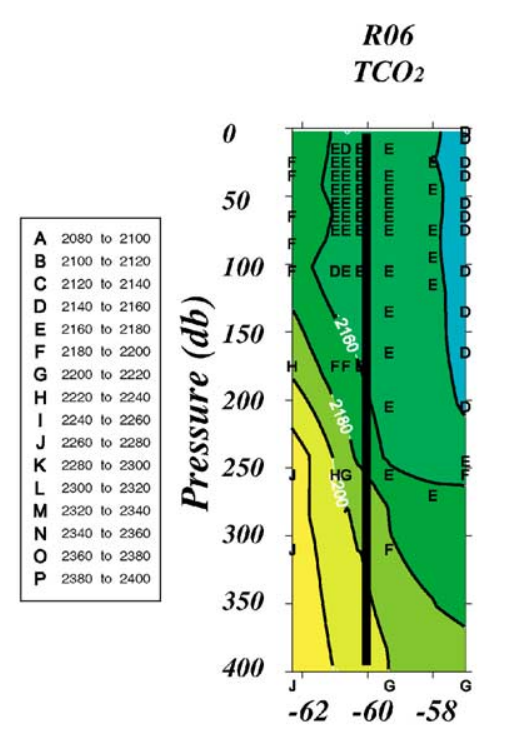

Original $\mathrm{TCO}_{2}$ Concentrations in $\mu \mathrm{mol} \mathrm{kg}^{-1}$

208021202160220022402280232023602400
Change of

$\mathrm{TCO}_{2}$ for $\mathrm{RO} 7$

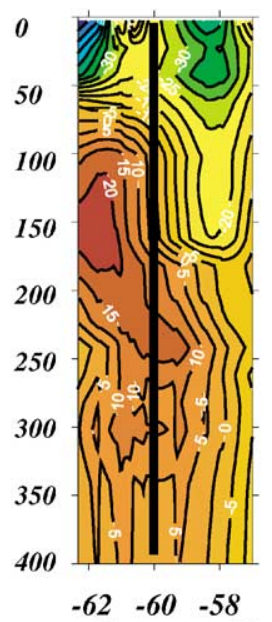

Degrees South Latitude
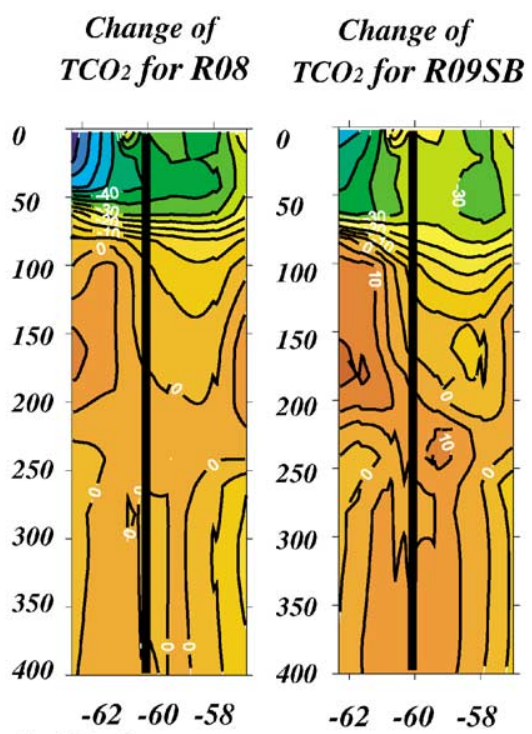

Fig. 12. The same as Fig. 10 except for total carbon dioxide $\left(\mathrm{TCO}_{2}-\mu \mathrm{mol} \mathrm{kg}{ }^{-1}\right)$.

year date $(365$ day $=$ January 1$)$ over a 1.5 year period to show mean seasonal changes. In an effort to characterize a seasonal cycle, the data from AESOPS have been combined with those obtained during the pre-and post-AESOPS period, as well as ROAVERRS programs. The year of observations is differentiated by various colors. The mean seasonal trend is represented by a curve based on a Spline function. The dashed section of the trend curves representing the period Marchmid-August is not reliably constrained due to the lack of observations.

The $\mathrm{pCO}_{2}$ data within an area $\left(60 \pm 1^{\circ} \mathrm{S}\right.$ between $\left.180 \pm 15^{\circ}\right)$ encompassing the $\mathrm{PF}$ are shown in Fig. 13. The top panel shows seasonal changes in SST with the mean temperature of $3.05 \pm 1.70^{\circ} \mathrm{C}$ for the 13,170 measurements shown in the figure. Since no measurements were made during the winter 6 months, the mean SST thus obtained may not represent an annual mean. However, this is consistent with the annual mean SST of $3.35 \pm 1.34^{\circ} \mathrm{C}$ obtained using the climatological daily mean SST of Levitus (1982) for this area. Accordingly, we use our mean SST value for representing this area. A wide range of SST up to $4^{\circ} \mathrm{C}$ observed in a narrow span of time suggests zonal and meridional variability caused by meandering of fronts within the area specified above. The second panel from the top (marked OBS) shows the surface water $\mathrm{pCO}_{2}$ values at the observed SST shown in the top panel. While the surface water $\mathrm{pCO}_{2}$ is nearly equal to the mean atmospheric $\mathrm{pCO}_{2}$ (horizontal dash-dot line) during the late austral winter, August-midNovember (year days 245-325), they are lower than the atmospheric $\mathrm{pCO}_{2}$ during the austral summer months, mid-November-mid-March (year days 320-440 Julian days). The drawdown of $\mathrm{pCO}_{2}$ during the austral summer (year days 335-425) reaches a maximum of $\sim 50 \mu \mathrm{atm}$ in 
Table 2

Net biological utilization of $\mathrm{CO}_{2}$ during the growth period, November-mid-January, estimated on the basis of seasonal amplitude of $\mathrm{pCO}_{2}$ observed in mixed layer waters between New Zealand and the Ross Sea $\left(180 \pm 15^{\circ} \mathrm{W}\right)$ during $1995-2000^{\mathrm{a}}$

\begin{tabular}{|c|c|c|c|c|}
\hline $\begin{array}{l}\text { Latitude ranges } \\
\text { Current region }\end{array}$ & $\begin{array}{l}55 \pm 1^{\circ} \mathrm{S} \\
\mathrm{N} \text { of } \mathrm{PF}\end{array}$ & $\begin{array}{l}60 \pm 1^{\circ} \mathrm{S} \\
\mathrm{APF}\end{array}$ & $\begin{array}{l}62 \pm 1^{\circ} \mathrm{S} \\
\mathrm{S} \text { of } \mathrm{PF}\end{array}$ & $\begin{array}{l}65 \pm 1^{\circ} \mathrm{S} \\
\mathrm{S} \text { of } \mathrm{PF}\end{array}$ \\
\hline Mean SST $\left({ }^{\circ} \mathrm{C}\right)$ for November-mid-March $( \pm=1 \sigma)$ & $6.68 \pm 0.98$ & $3.05 \pm 1.70$ & $1.70 \pm 1.71$ & $0.43 \pm 1.43$ \\
\hline $\begin{array}{l}\text { Annual mean SST }\left({ }^{\circ} \mathrm{C}\right) \text { based on Levitus climatological } \\
\text { daily mean values }\end{array}$ & $6.95 \pm 1.19$ & $3.35 \pm 1.34$ & $1.97 \pm 1.25$ & $0.31 \pm 1.02$ \\
\hline Revelle factor & 13.0 & 14.0 & 14.5 & 14.8 \\
\hline $\begin{array}{l}\text { Winter-summer difference for } \mathrm{pCO}_{2}(\mu \mathrm{atm}) \text { normalized } \\
\text { to mean SST }\end{array}$ & 80 & 110 & 130 & 190 \\
\hline Summer minimum $\mathrm{pCO}_{2}(\mu \mathrm{atm})$ in seawater & 330 & 300 & 300 & 250 \\
\hline Summer minimum $\mathrm{TCO}_{2}(\mu \mathrm{mol} / \mathrm{kg})$ & 2115 & 2100 & 2100 & 2100 \\
\hline $\begin{array}{l}\text { Calculated Winter-summer changes in } \mathrm{TCO}_{2} \text { concentration } \\
\left(\mu \mathrm{mol} \mathrm{kg}{ }^{-1}\right)\end{array}$ & $36(20 \pm 10)$ & $47(30 \pm 10)$ & $53(40 \pm 15)$ & $82(70 \pm 15)$ \\
\hline Summer mixed layer depth (m) & $35 \pm 15$ & $30 \pm 15$ & $25 \pm 15$ & $20 \pm 15$ \\
\hline Winter to summer $\mathrm{CO}_{2}$ deficit $\left(\mathrm{mol} \mathrm{m}^{-2}\right)$ & 1.3 & 1.5 & 1.4 & 1.7 \\
\hline Air-to-sea $\mathrm{CO}_{2}$ flux $\left(\mathrm{mol} \mathrm{m}^{-2}\right)$ & 0.2 . & 0.2 & 0.5 & 0.5 \\
\hline Net biological utilization of $\mathrm{CO}_{2}\left(\mathrm{~mol} \mathrm{~m}^{-2}\right)$ & 1.5 & 1.7 & 1.8 & 2.2 \\
\hline
\end{tabular}

\footnotetext{
a The values in the parentheses in the row for "Calculated Winter-summer changes in $\mathrm{TCO}_{2}$ concentration" represent the values estimated using the measured $\mathrm{TCO}_{2}$ values normalized at a constant salinity of 34.5. The Revelle factor has been estimated on the basis of the limited number of the measured alkalinity and $\mathrm{TCO}_{2}$ pairs. Since the availability of the seasonal data for $\mathrm{TCO}_{2}$ are far more limited than the $\mathrm{pCO}_{2}$ data, seasonal changes have been estimated using $\mathrm{pCO}_{2}$ data that give a better seasonal coverage. The values computed using the $\mathrm{pCO}_{2}$ data are consistent with those obtained by direct $\mathrm{TCO}_{2}$ measurements.
}

mid-summer (year day 365) which is below atmospheric partial pressure of $\sim 360 \mu \mathrm{atm}$. This suggests that the ocean water in this area is a sink for atmospheric $\mathrm{CO}_{2}$ during the austral summer months. Comparable data collected in the AZ just to the south of the PF $\left(62 \pm 1^{\circ} \mathrm{S}\right.$ between $180 \pm 15^{\circ}$ ) are shown in Fig. 14. In the AZ, the surface water is also a sink for $\mathrm{CO}_{2}$ during the summer months, reaching a maximum drawdown of about $65 \mu$ atm or surface water $\mathrm{pCO}_{2}$ about $70 \mu \mathrm{atm}$ below atmospheric levels. If one assumes that, during the remainder of the austral winter, March-August (year days 430-600), the surface water $\mathrm{pCO}_{2}$ is nearly equal to the mean atmospheric $\mathrm{pCO}_{2}$, as it was during August-mid-November, then the surface waters in the PF and $\mathrm{AZ}$ are a net sink for atmospheric $\mathrm{CO}_{2}$ on the annual average.

A global mean sea-air $\mathrm{CO}_{2}$ gas transfer rate of $0.0045 \mathrm{~mol} \mathrm{CO}_{2} \mathrm{~m}^{-2}$ month $^{-1}$ uatm $^{-1}$ is used to estimate the sea-air net $\mathrm{CO}_{2}$ flux. That is equivalent to the mean sea-air $\mathrm{CO}_{2}$ exchange (one-way) rate for the global oceans of $19 \mathrm{~mol} \mathrm{CO} \mathrm{m}^{-2} \mathrm{yr}^{-1}$ that was estimated on the basis of the carbon-14 partition in the atmosphere and oceans by Broecker et al. (1986). Since the annual mean wind speed within a zone between $59^{\circ} \mathrm{S}$ and $63^{\circ} \mathrm{S}$ is $10 \pm 2 \mathrm{~m} \mathrm{~s}^{-1}$ according to the NCEP 40-year mean monthly wind speed data and is greater than the global mean of $8.0 \pm 2.6 \mathrm{~m} \mathrm{~s}^{-1}$, the $\mathrm{CO}_{2}$ gas exchange rate used may underestimate the sea-air $\mathrm{CO}_{2}$ flux. Nevertheless, the drawdown of $\mathrm{pCO}_{2}$ during the summer months (mid-November-mid-March) in the PF $\left(60 \pm 1^{\circ} \mathrm{S}\right)$ region yields a net air-to-sea $\mathrm{CO}_{2}$ flux of about $0.7 \mathrm{~mol} \mathrm{CO}_{2} \mathrm{~m}^{-2}$. In the $\mathrm{AZ}\left(62 \pm 1^{\circ} \mathrm{S}\right)$, the air-to-sea flux is about 

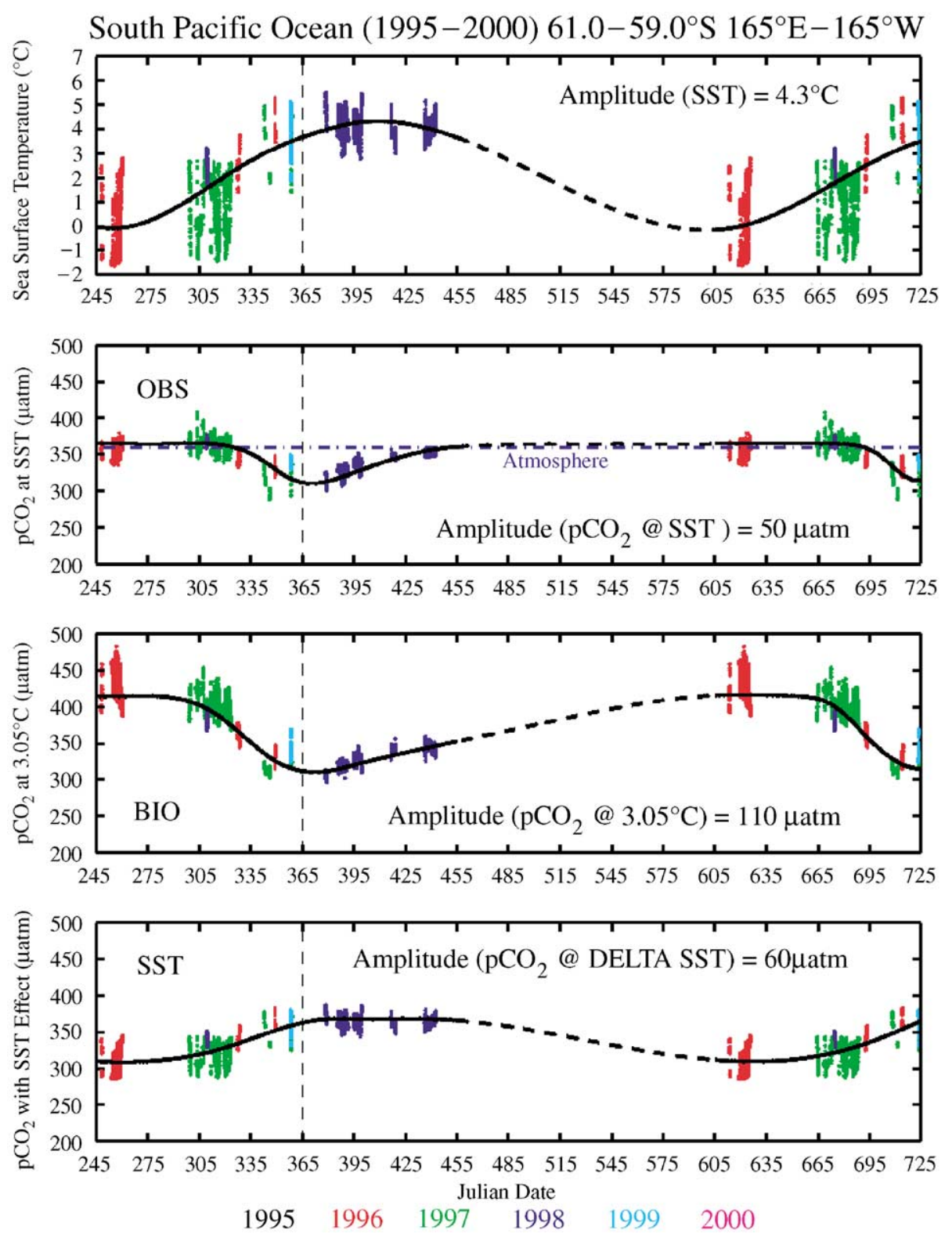

Fig. 13. Seasonal variation of SST and $\mathrm{pCO}_{2}$ in surface mixed layer observed during the years 1995-2000, within the area $59^{\circ} \mathrm{S}-61^{\circ} \mathrm{S}$ and $165^{\circ} \mathrm{E}-165^{\circ} \mathrm{W}$. The data obtained in different years are plotted against year dates covering a $1.5-\mathrm{yr}$ period, day $245-$ day 725 . The day 365 is indicated with a vertical dashed line representing January 1 . The data between days 245 and 365 are repeated for the period, 610-730 days. The top panel shows the observed SST; the second panel marked "OBS" shows the observed $\mathrm{pCO}_{2}$ data in surface waters; the third panel marked "BIO" shows the $\mathrm{pCO}_{2}$ values normalized to a constant temperature representing an annual mean for the area, and reflects biological effects on $\mathrm{pCO}_{2}$; and the bottom panel marked "SST" shows the changes of $\mathrm{pCO}_{2}$ in seawater due to temperature changes alone. 

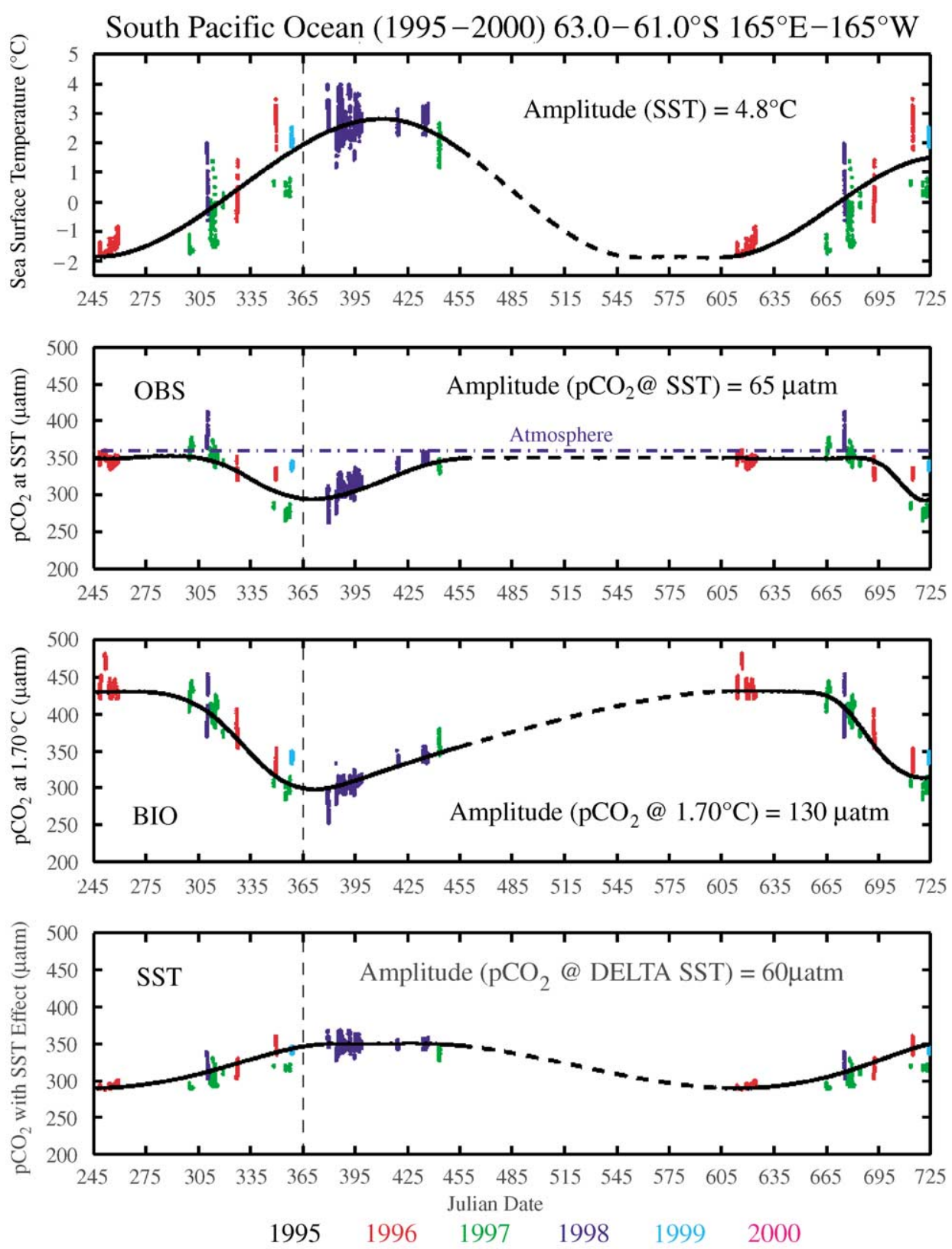

Fig. 14. Same as Fig. 12 except for the area $61^{\circ} \mathrm{S}-63^{\circ} \mathrm{S}$ and $165^{\circ} \mathrm{E}-165^{\circ} \mathrm{W}$.

$0.4 \mathrm{~mol} \mathrm{CO} \mathrm{Cm}^{-2}$ for the same 4-month period. These fluxes compare with the mean net $\mathrm{CO}_{2}$ flux over the global oceans of about $0.2 \mathrm{~mol} \mathrm{CO}_{2} \mathrm{~m}^{-2}$ for 4 months (or $0.54 \mathrm{~mol} \mathrm{CO}_{2} \mathrm{~m}^{-2}$ for $1 \mathrm{yr}$ ). Hence, during the summer 4-month period, these areas take up atmospheric $\mathrm{CO}_{2}$ at a rate 2-3 times as fast as the mean global ocean rate. On the other hand, the net $\mathrm{CO}_{2}$ flux in these areas is 
expected to be nearly zero during the rest of year since the sea-air $\mathrm{pCO}_{2}$ difference is likely to be small due to upwelling and the area is covered with ice field. In these areas, wind speeds are quite variable, and since the wind speed dependence of sea-air gas transfer rate is uncertain, the mean $\mathrm{CO}_{2}$ gas exchange rate over the global ocean was chosen rather than a specific formulation for the wind speed dependence of the gas transfer coefficient. Therefore, the uncertainties in the air-to-sea $\mathrm{CO}_{2}$ flux values cited above are estimated to be as much as $\pm 50 \%$. However it is important to note that the removal of $\mathrm{CO}_{2}$ by photosynthesis depletes $\mathrm{TCO}_{2}$ in the surface water during the summer and thus lowers the $\mathrm{pCO}_{2}$ in surface water below the atmospheric level. This should cause a substantial air-to-sea flux of $\mathrm{CO}_{2}$ in the summer to replace $\mathrm{CO}_{2}$ that was removed by photosynthesis. The organic particulate matter thus formed sinks into the deep sea. This surface water is cooled during fall through winter and is convectively mixed down into AAIW. These processes represent important pathways for atmospheric $\mathrm{CO}_{2}$ into the deep ocean interior for storage.

\subsection{Biological utilization of $\mathrm{CO}_{2}$ in mixed layer waters}

During the months of November-mid-January (year days 320-380 in Figs. 13 and 14), the surface water $\mathrm{pCO}_{2}$ values are reduced while the SST increases as much as $4.3^{\circ} \mathrm{C}$. If the chemical composition of the seawater were constant, this warming should have increased the $\mathrm{pCO}_{2}$ in seawater by about $18 \%$ or $60 \mu \mathrm{atm}$. This suggests that the effects of biological $\mathrm{CO}_{2}$ drawdown counter the increasing effects of temperature on seawater $\mathrm{pCO}_{2}$.

To differentiate between the biological and temperature effects on $\mathrm{pCO}_{2}$, the observed seawater $\mathrm{pCO}_{2}$ is normalized to a constant temperature using a temperature effect, $\left(\partial \ln \mathrm{pCO}_{2} / \partial T\right)$, of $0.0423^{\circ} \mathrm{C}^{-1}$ as reported by Takahashi (1993). The third panel (marked BIO) in Fig. 13 shows the $\mathrm{pCO}_{2}$ values normalized to a constant temperature of $3.05^{\circ} \mathrm{C}$ representing the 1 mean of SST measured in the area. Changes in temperature-normalized $\mathrm{pCO}_{2}$ primarily reflect the effect of changes in $\mathrm{TCO}_{2}$. The low values during the summer months, year days 305-425 (mid-Novembermid-March), indicate biological drawdown of $\mathrm{CO}_{2}$, whereas the high values during winter months, year days 245 though 425 (August-mid-November), represent the effect of upwelling of subsurface waters rich in $\mathrm{CO}_{2}$ and nutrients. Therefore, the amplitude of the temperaturenormalized $\mathrm{pCO}_{2}$ values, $110 \mu \mathrm{atm}$ (Fig. 13), represents an approximation for the net biological utilization of $\mathrm{CO}_{2}$ that occurred through the growing season. Using the Revelle factor of 14.0 estimated for the seawater in this area using the limited number of the measured alkalinity and $\mathrm{TCO}_{2}$ values, this $\mathrm{pCO}_{2}$ drawdown corresponds to a $\mathrm{TCO}_{2}$ decrease of $47 \mu \mathrm{mol} \mathrm{kg} \mathrm{k}^{-1}$. Since the availability of the seasonal data for $\mathrm{TCO}_{2}$ and total alkalinity are far more limited than the $\mathrm{pCO}_{2}$ data, seasonal changes have been estimated using $\mathrm{pCO}_{2}$ data that give a better seasonal coverage. The values computed using the $\mathrm{pCO}_{2}$ data are consistent with those obtained by direct $\mathrm{TCO}_{2}$ measurements as shown in Table 2. The mean mixed-layer depth during the month of January, when $\mathrm{pCO}_{2}$ in seawater is a minimum, has been estimated to be about $30 \mathrm{~m}$ (Monterey and Levitus, 1997). The product of the drawdown in the $\mathrm{TCO}_{2}$ concentration and the summer mixedlayer thickness gives an estimate for the $\mathrm{CO}_{2}$ deficit per unit ocean surface area. This deficit results from the combined effects of (a) the net biological utilization of $\mathrm{CO}_{2}$, (b) the sea-air gas transfer of $\mathrm{CO}_{2}$, and (c) the vertical mixing of $\mathrm{CO}_{2}$-rich subsurface waters into the mixed layer. The air-to-sea $\mathrm{CO}_{2}$ flux during the onset of phytoplankton bloom through the mid-January when $\mathrm{pCO}_{2}$ is drawn 
down to a minimum value is estimated as discussed earlier. The effect of vertical mixing of high $\mathrm{CO}_{2}$ deep waters into the mixed layer may be considered to be small, since the mixed layer shallows with progressing seasons during the growth period. In some areas of the Southern Ocean a temperature minimum layer that represents remnant mixed-layer waters from the previous winter underlies the mixed layer. In these areas, the effect of deep-water mixing on the $\mathrm{CO}_{2}$ concentration in mixed-layer waters should be negligibly small. Neglecting the deep-water mixing effect, the net biological utilization during the growth period may be estimated as shown in Table 2 . The net biological utilization of $\mathrm{CO}_{2}$ thus estimated should be considered to be a minimum estimate since the effects of deep-water mixing and that of gradual or step-wise decrease in mixedlayer depths with progressing seasons are neglected. In estimating the biological utilization, one of the most uncertain terms is the mixed-layer thickness, which differs depending upon the criteria and parameters (density, temperature or concentrations of nutrients and oxygen) used to define it. Since the $\mathrm{CO}_{2}$ data used for this study were obtained over the six year period, 1995-2000, the climatological mean mixed-layer depths estimated by Monterey and Levitus (1997) for December and January were used rather than computed from a limited number of CTD observations obtained during the AESOPS field program in 1996-1997.

The net biological utilization values that have been computed at the four zones, $55 \pm 1^{\circ} \mathrm{S}$, $60 \pm 1^{\circ} \mathrm{S}, 62 \pm 1^{\circ} \mathrm{S}$ and $65 \pm 1^{\circ} \mathrm{S}$, are presented in Table 2 . These utilization values represent the amount of $\mathrm{CO}_{2}$ utilized during the 2.5-month period between the initiation of phytoplankton blooms and the mid-January when seawater $\mathrm{pCO}_{2}$ reached a minimum. The net $\mathrm{CO}_{2}$ utilization or the net community production during the 2.5 growing months appears to increase southward from $1.5 \mathrm{~mol} \mathrm{C} \mathrm{m}^{-2}$ at $55^{\circ} \mathrm{S}$ to $2.2 \mathrm{~mol} \mathrm{Cm}^{-2}$ at $65^{\circ} \mathrm{S}$, but are indistinguishable across the PF that lies at about $60^{\circ} \mathrm{S}$. On the basis of the uncertainties in various parameters used for computing the net carbon utilization, the utilization rates presented in Table 2 are uncertain to $\pm 20 \%$ relative to each other and $\pm 50 \%$ in the overall accuracy. Nelson et al. (2001) compared the annual organic carbon fluxes obtained using several different methods during the AESOPS program. The net community production and new production values estimated for three zones located between $55^{\circ} \mathrm{S}$ and $65.5^{\circ} \mathrm{S}$ along the $170^{\circ} \mathrm{W}$ meridian are greater than our values by $30-50 \%$. Since our estimates represents the production occurred in the first 2.5 months of the spring bloom period, they should be smaller than the annual productions.

\section{Summary}

Flow of the ACC is concentrated in narrow jets, coinciding with the principal fronts, which are interspersed with broader zones of reduced or even reversed flow, creating large shear within the water column (Whitworth, 1980; Orsi et al., 1995) and where physical conditions are extremely dynamic. In particular, the ACC cruises concentrated on the PFZ, located between the PF at $\sim 60^{\circ} \mathrm{S}$ and the SAF at $\sim 54^{\circ} \mathrm{S}$, and the AZ, south of the PF. Here we have endeavored to describe the seasonal evolution of the macronutrients, fCHL, POC, $\mathrm{TCO}_{2}$ and $\mathrm{pCO}_{2}$ in the upper $400 \mathrm{~m}$ of the PFZ during the evolution of the seasonal phytoplankton bloom found in this area. Even though it must be kept in mind, when using these data to represent the seasonal variability at one location within the ACC, that the ACC is a dynamic zonal current. We have shown that the majority of the temporal changes in nutrient distributions within mixed layer waters in the PFZ is 
due to seasonal biological productivity. We have shown that at least in this sector of the ACC, the productivity of the upper waters does not appear to be controlled by availability of nutrients. At $170^{\circ} \mathrm{W}$, the data shown here display depletion of up to $\sim 30 \%$ of the inorganic nitrogen, $\sim 50 \%$ of the phosphate and $\sim 95 \%$ of the dissolved silicate during the growing season. As the growth diminished, concentrations appear to rapidly return to their pre-bloom concentrations. This is to be expected with the nearly vertical isopycnals found in the ACC, as well as the rapid increase in mixed-layer depth at the end of the summer growing season, there is a very efficient exchange between the surface and nutrient-rich deep waters. While there is significant depletion of inorganic nitrogen, phosphate and silicate associated with the seasonal phytoplankton bloom in this region, none of the nutrients, except perhaps silicate are actually depleted within the euphotic zone. Inspection of the ratios of apparent nutrient drawdown near $64^{\circ}$ suggest $\mathrm{N} / \mathrm{P}$ apparent drawdowns to have a ratio of $\sim 10$ and N/Si apparent drawdowns to have a ratio of $>4$. These ratios suggest a bloom that was dominated by Fe limited diatoms (e.g. Smith et al., 2000; Sweeney et al., 2000).

It is important to note that while, during the summer, the removal of $\mathrm{CO}_{2}$ by photosynthesis depletes $\mathrm{TCO}_{2}$ in the surface water in the PFZ and the AZ just to the south of the PFZ, there is a substantial air-to-sea flux of $\mathrm{CO}_{2}$ in the summer to replace $\mathrm{CO}_{2}$ that was removed by photosynthesis, and the formation of organic matter that sinks into the deep sea. This surface water is cooled during fall through winter and is convectively mixed down into AAIW. During the summer months, these areas take up atmospheric $\mathrm{CO}_{2}$ at a rate 2-3 times as fast as the mean global ocean rate. On the other hand, the net $\mathrm{CO}_{2}$ flux in these areas is nearly zero during the rest of year. This represents an important process for the transport of atmospheric $\mathrm{CO}_{2}$ into the deep ocean interior for storage.

Finally, the net $\mathrm{CO}_{2}$ utilization or the net community production during the 2.5 growing months between the initiation of phytoplankton blooms and mid-January when seawater $\mathrm{pCO}_{2}$ reached a minimum appears to increase from $1.5 \mathrm{~mol} \mathrm{C} \mathrm{m}{ }^{-2}$ at $55^{\circ} \mathrm{S}$ to $2.2 \mathrm{~mol} \mathrm{C} \mathrm{m}^{-2}$ at $65^{\circ} \mathrm{S}$, but are indistinguishable across the PF that lies at about $60^{\circ} \mathrm{S}$.

\section{Acknowledgements}

We wish to give our thanks to 3 anonymous reviewers and Dr. Robert Anderson for their insightful comments and suggestions that have served to significantly improve the paper.

Our participation in the US JGOFS AESOPS experiment and subsequent data analysis were funded by the US National Science Foundation. This project would never have come into being without the persistent and dedicated efforts of the project leaders, Robert Anderson and Walker O. Smith. Antarctic Support Associates provided logistic and technical support, which we deeply appreciate. This program could not have been accomplished without the outstanding, enthusiastic support we received from the officers and crew of the $R / V$ Roger Revelle.

Collection and editing of the hydrographic and $\mathrm{CO}_{2}$ data reported here required the dedicated efforts of a large number of individuals (Heather Anderson, Susan Becker, Rebecca Esmay, David Chipman, Mark Cook, Elizabeth Degler, Dennis Guffy, Scott Hiller, Jason Jolliff, Jeff Kinder, Katherine Krogslund, Leonard Lopez, Robert Masserini, Douglas Masten, Calvin Mordy, Stacey Morgan, Chris Nugent, Denis Pierrot, James Postel, Erik Quiroz, Stephany Rubin, Sarah 
Searson, Robert Williams, Xiarong Zhu). From the beginning, we decided that rather than building a large hydrographic group at a single institution, the needs of JGOFS would best be met by combining the talents that already existed at a number of institutions. With cross training and considerable hard work, the hydrographic team collected data that meet or exceed JGOFS and WOCE standards and were available to all Antarctic Polar Frontal Zone PI's within 12 months of the end of the cruises. This is US JGOFS Contribution Number 706.

\section{References}

Arrigo, K.R., Robinson, D.H., Worthen, D.L., Dunbar, R.B., DiTullio, G.R., van Woert, M., Lizotte, M.P., 1999. Phytoplankton community structure and drawdown of nutrients and $\mathrm{CO}_{2}$ in the Southern Ocean. Science 283, 265-2567.

Banse, K., 1996. Low seasonality of low concentrations of surface chlorophyll in the Subantarctic water ring: underwater irradiance, iron, or grazing? Progress in Oceanography 37, 241-291.

Barth, J.A., Cowles, T.J., Pierce, S.D., 2001. Mesoscale physical and bio-optical structure of the Antarctic Polar Front near $170^{\circ} \mathrm{W}$ during spring. Journal of Geophysical Research, submitted for publication.

Broecker, W.S., Ledwell, J.R., Takahashi, T., Weiss, R.F., Merlivat, L., Memery, L., Peng, T.-H., Jahne, B., Munnich, K.O., 1986. Isotopic versus micrometeorologic ocean $\mathrm{CO}_{2}$ fluxes: a serious conflict. Journal of Geophysical Research 91, 10517-10527.

Chipman, D.W., Marra, J., Takahashi, T., 1993. Primary production at $47^{\circ} \mathrm{N}$ and $20^{\circ} \mathrm{W}$ in the North Atlantic Ocean: a comparison between the $\mathrm{C}_{14}$ incubation method and the mixed layer carbon budget. Deep-Sea Research I 40, 151-169.

Deacon, G.E.R., 1937. The hydrology of the southern ocean. Discovery Reports 15, 1-24.

De Baar, H.J.W., de Jong, J.T.M., Bakker, D.C.E., Löscher, B.M., Veth, C., Bathmann, U., Smetecek, V., 1995. Importance of iron for phytoplankton spring blooms and $\mathrm{CO}_{2}$ drawdown in the Southern Ocean. Nature 373, 412-415.

Gardner, W.D., Gundersen, J.S., Richardson, M.J., Walsh, I.D., 1999. The role of diel variations in mixed-layer depth on the distribution, variation, and export of carbon and chlorophyll in the Arabian Sea. Deep-Sea Research II 46, 1833-1858.

Hoppema, M., Fahrbach, E., de Baar, H.J.W., 2000. Surface layer balance of the southern Antarctic Circumpolar Current (prime meridian) used to derive carbon and silicate consumptions and annual air-sea exchange for $\mathrm{CO}_{2}$ and oxygen. Journal of Geophysical Research 105, 11359-11471.

Jacques, G., 1989. Primary productivity in the open Antarctic Ocean during the Austral summer, a review. Vie et Milieu $39,1-17$.

Levitus, S., 1982. Climatological Atlas of the World Ocean. NOAA Professional Paper, 13, US Department of Commerce, p. 173.

Millero, F.J., Xhu, X., Pierrot, D., Jolliff, J., Degler, E., 1999. The Carbon Dioxide System in the Southern Ocean during the JGOFS APFZ Transit, Survey I and Process I Cruises. Rosentiel School of Marine and Atmospheric Science, University of Miami, Technical Report No. RSMAS-99-005, July 1999.

Mitchell, B.G., Brody, E.A., Holm-hansen, O., McClain, C., Bishop, J., 1991. Light limitation of phytoplankton biomass and macronutrient utilization in the Southern Ocean. Limnology and Oceanography 36, 1662-1677.

Monterey, G., Levitus, S., 1997. World Ocean Atlas for Mixed Layer Depths. NOAA Atlas NESDIS 14, US Department of Commerce, Washington, DC.

Nelson, D.M., Anderson, R.F., Barber, R.T., Brzezinski, M.A., Buesseler, K.O., Chase, Z., Collier, R.W., Dickson, M.-L., François., R., Hiscock, M.R., Honjo, S., Marra, J., Martin, W.R., Sambrotto, R.N., Sayles, F.L., Sigmon, D.E., 2001. Vertical budgets for organic carbon and biogenic silica in the Pacific Sector of the Southern Ocean, 1996-1998. Deep-Sea Research II, submitted.

Nowlin Jr., W.D., Whitworth III, T., Pillsbury, R.D., 1997. Structure and transport of the antarctic circumpolar current at drake passage. Journal of Physical Oceanography 7, 778-802d. 
Orsi, A.H., Whitworth III, T., Nowlin Jr., W.D., 1995. On the meridional extent and fronts of the Antarctic Circumpolar Current. Deep-Sea Research I 42, 641-673.

Read, J.F., Pollard, R.T., Morrison, A.L., Symon, C., 1995. On the southerly extent of the Antarctic Circumpolar Current in the southeastern Pacific. Deep-Sea Research II 45 (4-5), 933-954.

Smetacek, V., De Baar, H.J.W., Bathmann, U.V., Lochte, K., Rutgers Van Der Loeff, M.M., 1997. Ecology and biogeochemistry of the Antarctic Circumpolar Current during austral spring: a summary of Southern Ocean JGOFS cruise ANT X/6 of R.V. Polarstern. Deep-Sea Research II 44 (1-2), 1-21.

Smith Jr., W.O., Nelson, D.M., 1985. Phytoplankton bloom produced by a receding ice edge in the Ross Sea: spatial coherence with the density field. Science 227, 163-167.

Smith, W.O., Anderson, R.F., Moore, J.K., Codispoti, L.A., Morrison, J.M., 2000. The US southern ocean joint global ocean flux study: an Introduction to AESOPS. Deep-Sea Research II 47 (15-16), 3073-3094.

Sweeney, C., Smith, W.O., Hales, B., Bidigare, R.R., Carlson, C.A., Codispoti, L.A., Gordon, L.I., Hansell, D.A., Millero, F.J., Park, M.-O., Takahashi, T., 2000. Nutrient and carbon removal ratios and fluxes in the Ross Sea, Antarctica. Deep-Sea Research II 47 (15-16), 3395-3422.

Takahashi, T., 1993. Measurements of the total $\mathrm{CO}_{2}$ concentration and partial pressure of $\mathrm{CO}_{2}$ in seawater during WOCE expeditions P-16, P-17, and P-19 in the south pacific ocean, October, 1992-April, 1993. Final Technical Report of Grant No. DE-FCO2-93ER61539 to US Department of Energy, Lamont-Doherty Earth Obs., Palisades, NY 10964, p. 124.

Tréguer, P., Jacques, G., 1992. Dynamics of nutrients and phytoplankton, and fluxed of carbon, nitrogen and silicon in the Antarctic Ocean. Polar Biology 12, 149-162.

Whitledge, T.E., Malloy, S.C., Patton, C.J., Wirick, C.D., 1981. Automated Nutrient Analyses in Seawater. Brookhaven National Laboratory Report BNL 51398, 216pp.

Whitworth III, T., 1980. Zonation and geostrophic flow of the Antarctic Circumpolar Current at Drake Passage. DeepSea Research I 27, 497-507. 